\title{
Epigenetic gold occurrence in a Paleoproterozoic meta-evaporitic sequence in the Rompas-Rajapalot Au system, Peräpohja belt, northern Finland
}

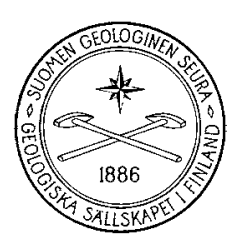

VERTAISARVIOITU KOLLEGIALT GRANSKAD PEER-REVIEWED
Jukka-Pekka Ranta ${ }^{*}$, Ferenc Molnár ${ }^{2}$, Eero Hanski ${ }^{1}$ AND NICK $\mathrm{COOK}^{3}$

${ }^{1}$ Oulu Mining School, University of Oulu, P.O.BOX 3000, FI-90014, Finland

${ }^{2}$ Geological Survey of Finland, P.O. Box 96, FI-02151 Espoo, Finland

${ }^{3}$ Mawson Resources Ltd., 1305-1090 West Georgia Street Vancouver, BC V6E 3V7, Vancouver, Canada

\section{Abstract}

The Rompas-Rajapalot gold prospect is located in the northern part of the Paleoproterozoic Peräpohja belt. It covers an area of at least $10 \times 10 \mathrm{~km}$ and comprises various styles of gold mineralization ranging from localized high-grade Au pockets in uraniniteand pyrobitumen-bearing calcsilicate-carbonate-quartz veins in mafic metavolcanic rocks (Rompas area) to disseminated gold grains in Fe-Mg-rich metasediments and quartz-tourmaline-sulfide-native gold veins (Palokas area). This study deals with the petrography and mineral chemistry of the gold mineralization at Palokas, which occurs in the eastern part of the Rompas-Rajapalot prospect.

Major and trace element data and fluid inclusion characteristics of tourmaline are used to evaluate the origin and the pressure-temperature-fluid composition parameters of hydrothermal fluids. Whole-rock geochemical analyses are utilized to evaluate the nature of the protolith of the host rocks. Gold occurs in a native form in at least two different textural settings: 1) single, relatively coarse grains disseminated among the rock-forming silicates in cordierite-orthoamphibole rocks and 2) smaller grains occurring in fractures of tourmaline in quartz-sulfide-tourmaline breccias and in fractures of chloritized cordierite-orthoamphibole rocks adjacent to the tourmaline-rich breccias. Fracture-related gold is associated with Bi-Se-S-bearing tellurides, native $\mathrm{Bi}$, molybdenite, chalcopyrite, and pyrrhotite. Coarser-grained disseminated gold were not found to be clearly associated with sulfides nor any fractures. Statistical correlations show that the Au concentration correlates strongly with $\mathrm{Te}, \mathrm{Cu}, \mathrm{Co}, \mathrm{Se}, \mathrm{Bi}, \mathrm{Mo}$, and $\mathrm{Ag}$ $(\rho=0.730-0.619)$ whereas Au correlates moderately with As, Fe, W $(\rho=0.523-0.511)$ and to a lesser extent with $\mathrm{U}, \mathrm{Pb}$, and $\mathrm{Ni}(\rho=0.492-0.407)$. Gold has the strongest negative correlations with $\mathrm{Sr}$ and $\mathrm{Ca}$.

The chondrite-normalized REE patterns of tourmaline from the Au-mineralized rocks (both vein type and host-rock tourmaline) and the late- to post-orogenic granite partly overlap and show similar LREE-enriched trends, with the enrichment being lower in tourmaline from the granite. Fluid inclusion studies from tourmaline in gold-bearing 
quartz-tourmaline-sulfide veins indicate that the veins were formed from $\mathrm{H}_{2} \mathrm{O}-\mathrm{Na}_{2} \mathrm{O}-\mathrm{CO}_{2}-$ $\mathrm{CH}_{4}-\left(\mathrm{H}_{2} \mathrm{~S}\right)$ fluids in a boiling system under pressure conditions ranging from lithostatic to hydrostatic, with the depth being $\sim 5 \mathrm{~km}$ and the temperature $\sim 300^{\circ} \mathrm{C}$. The properties of the ore-forming fluids support the genetic link between the late- to post-orogenic granitoid magmatism at $\sim 1.78 \mathrm{Ga}$ and the formation of the fracture-hosted gold mineralization, suggested based on earlier studies (including Re-Os-molybdenite age and boron isotope data from tourmaline). Based on the whole-rock geochemistry, it is highly plausible that the cordierite-orthoamphibole rocks and interlayered calcsilicatealbite rocks are part of a basin-wide lacustrine, at least partly evaporitic, sequence. The protolith of the cordierite-orthoamphibole rock was most probably a lake-margin sedimentary pile with abundant Mg-rich clays.

Keywords: gold, fluid inclusions, Paleoproterozoic, Peräpohja belt, Rompas-Rajapalot, Palokas, Finland

*Corresponding author (e-mail: jukka-pekka.ranta@oulu.fi)

Editorial handling: Igor S. Puchtel (ipuchtel@mail.umd.edu)

\section{Introduction}

Multiple gold occurrences have recently been discovered in the northern part of the Peräpohja belt, one of the Paleoproterozoic supracrustal belts in northern Finland. The latter were deposited on the Archean basement and metamorphosed and deformed during the Svecofennian orogeny (e.g., Vanhanen, 2001; Molnár et al., 2016; Ranta et al., 2017). The Au occurrences are associated with different host rocks with variable alteration types, and in most cases, the mechanism of their generation has previously been regarded as similar to that of orogenic gold deposits with "atypical metal associations" occurring in other Karelian supracrustal belts (e.g., the Central Lapland greenstone belt, the Kuusamo belt; Eilu, 2015). Recent detailed studies by Molnár et al. (2016), Nykänen et al. (2017) and Ranta et al. (2017) have shown that some of the deposits possess mineralogical, petrological and geochemical features that do not match those of orogenic gold deposits found in Archean or Paleoproterozoic greenstone belts globally (e.g., Groves et al., 1998; Goldfarb et al., 2001; Goldfarb and Groves,
2015). As a result, the deposits have been termed "Rompas-type Au deposits" (Molnár et al., 2016). Furthermore, the intense multiple deformation and episodes of pre-, syn- and post-metamorphic hydrothermal alteration (Molnár et al., 2017a) make the identification of the protoliths in the northern part of the Peräpohja belt problematic.

The Palokas gold mineralization was discovered in 2012 by Mawson Resources Ltd. It is part of a larger gold-productive hydrothermal system in the northern part of the Peräpohja belt (Fig. 1), which is currently called the Rompas-Rajapalot $\mathrm{Au}$ project (Vanhanen et al., 2015). Two main mineralized areas, Rompas in the west and Rajapalot in the east, are approximately $6-8 \mathrm{~km}$ apart and differ in terms of their host rock, mineralization style, and grade. In the Rajapalot area, several locations with disseminated and vein-hosted gold have been identified; among them, the currently most significant is the gold occurrence at Palokas (Fig. 2). The Rompas Au-U mineralization is hosted by deformed calcsilicate-carbonate-quartz veins in mafic metavolcanic rocks (Vanhanen et al., 2015; Molnár et al., 2016). Uranium- and pyrobitumen-bearing parts of the veins have locally 
very high gold grades (>10000 g/t Au; Vanhanen et al., 2015). Rompas-type mineralization has also been identified in the Rajapalot area and between the Rajapalot and Rompas areas, but at Rajapalot, the gold is generally not associated with uranium enrichment and high-grade gold zones are confined to gold dissemination and gold in quartz vein stockworks in Mg-metasomatized metavolcanic and metasedimentary rocks (Hudson, 2013; Cook, 2017).

The focus of this paper is on the Palokas Au occurrence in the Rajapalot area. It is hosted by a metamorphosed Ca-poor, $\mathrm{Mg}$-Fe-rich rock unit interlayered with albitized calcsilicate rocks and intrusive amphibolites (Ranta et al., 2015a; Ranta et al., 2017). Gold occurs in sulfide-rich dissemination in $\mathrm{Fe}-\mathrm{Mg}$-rich rocks and tourmalinerich, sulfide-bearing quartz veins. Genetic classification of the mineralization has been problematic due to the atypical features and lack of information on this newly discovered area (Eilu, 2015). Chemical and $\mathrm{U}-\mathrm{Pb}$ ages of uraninite from Rompas suggest that gold deposition took place around $1.75 \mathrm{Ga}$ (Molnár et al., 2016; 2017a). In addition, ReOs- dating of molybdenite associated with gold at Palokas has yielded an age of $1.78 \pm 0.01 \mathrm{Ga}$ (Molnár et al., 2017a) indicating that the mineralization may be synchronous with the emplacement of late- to post-orogenic granitoids in the vicinity of the mineralization. This relationship is also supported by the identical boron isotope composition of the tourmaline (from -4 to $0 \%$ $\delta^{11} \mathrm{~B}$ ) that is associated with gold at Rajapalot and occurs in a $1.78 \mathrm{Ga}$ pegmatite granite (Ranta et al., 2017), as well as in the tourmaline-bearing alteration zones at Rompas (from -2 to $+0.5 \%$ $\delta^{11} \mathrm{~B}$; F. Molnár, unpublished data). The geochronological, mineralogical, and boron isotope data suggest that the mineralized zones at Rompas and Rajapalot may be parts of the same large hydrothermal system. This relationship is also supported by the recent discoveries of disseminated gold mineralization at "East Rompas Au" (Cook, 2017) adjacent to the main Rompas Au-U trend (Fig. 2).
This study deals with the petrography and mineral chemistry of the gold mineralization at Palokas. Major and trace element data, together with fluid inclusion characteristics of tourmaline, are also used to evaluate the origin and the pressuretemperature-fluid composition parameters of hydrothermal fluids and whole-rock geochemical data are used to evaluate the nature of the protolith of the host rocks. Based on the overall features of the Rompas-Rajapalot area, the genetic classification of the peculiar Au mineralization in the northern part of the Peräpohja belt is discussed.

\section{Regional geological setting}

The Peräpohja belt (PB) is one of the Paleoproterozoic supracrustal belts covering the Archean Karelian craton (Fig. 1). It is bordered by the Central Lapland granitoid complex in the north and east and the Archean Pudasjärvi gneiss complex in the south. In the west, the NS-trending Pajala shear zone separates the belt from the Norrbotten craton. The evolution of the sedimentary-volcanic basin started after the emplacement of the ca. $2.44 \mathrm{Ga}$ mafic-ultramafic layered intrusions and their uplift and partial erosion (Huhma et al., 1990; Iljina \& Hanski, 2005). These intrusions thus give a maximum depositional age for the Peräpohja belt.

Table 1 summarizes the stratigraphy of the Peräpohja belt. The sedimentary rocks of the lowermost portion of the $\mathrm{PB}$, which are assigned to the Kivalo Group (Perttunen et al., 1995), comprise quartz-sandstone with minor conglomerate and shallow-water carbonate rocks. They are accompanied by mafic volcanic rocks (e.g. Runkaus and Jouttiaapa Formations), dikes and sills emplaced in a time interval of ca. 2.4-2.06 Ga. In addition, the Kivalo Group also contains evaporitic rocks of the Petäjäskoski Formation (Kyläkoski et al., 2012) and coarse glacimarine sedimentary rocks (Vanhanen et al., 2015). The upper part of the PB belongs to the Paakkola Group consisting of pillow lava, mafic and felsic tuff, and turbiditic-pelitic rocks with carbonaceous material-rich sulfidic intercalations. 


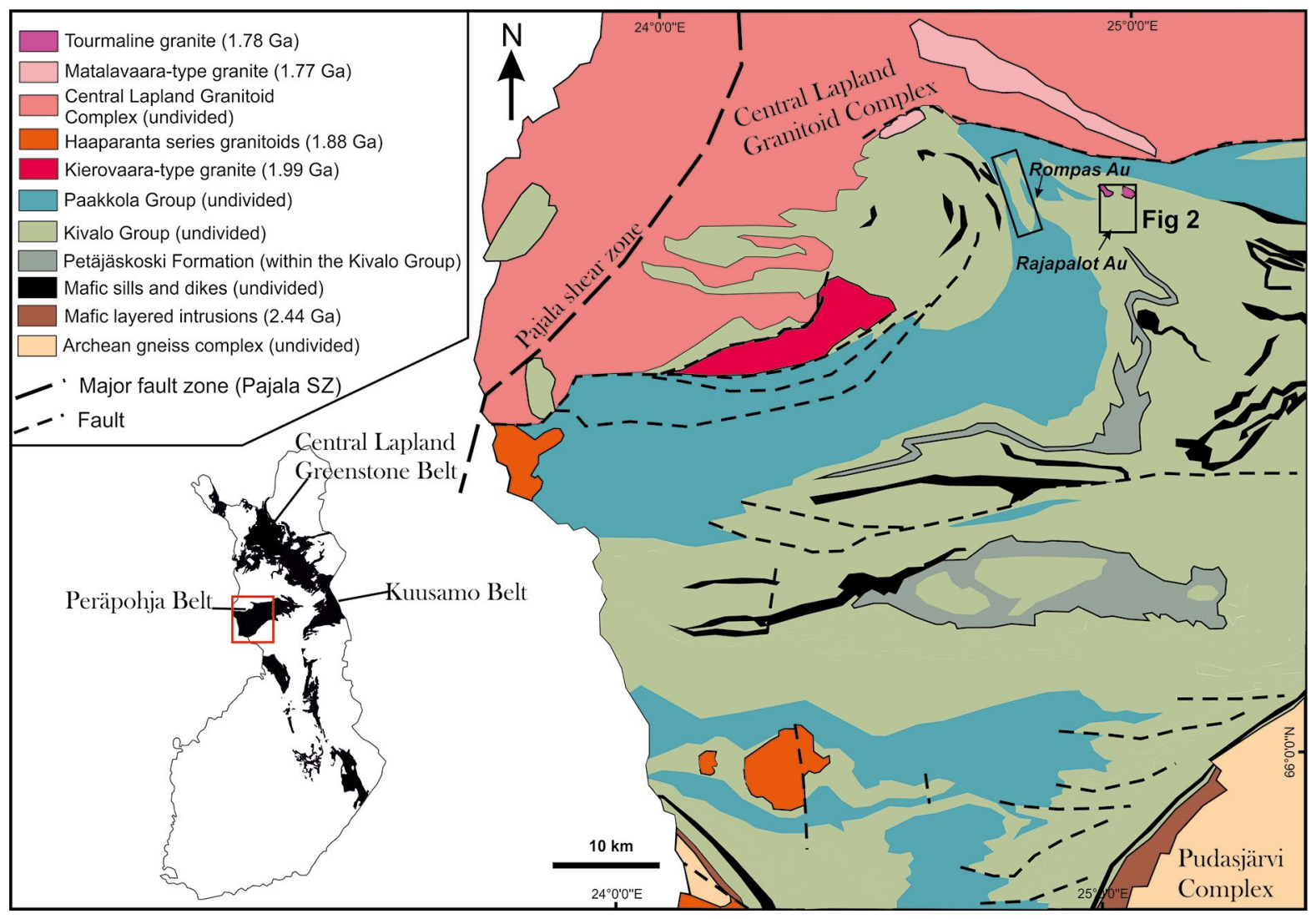

Figure 1. Geological map of the western part of the Peräpohja belt (modified after the DigiKP version 2.1. (“Digital map database for bedrock geology of Finland" [electronic resource], Geological Survey of Finland; referred on 27.6.2017) and Ranta et al. (2017). The Petäjäskoski Formation is delineated after Kyläkoski et al. (2012). The Rompas and Rajapalot prospects are framed with rectangles.

Based on the age of detrital zircon grains, the maximum age of the stratigraphically youngest turbiditic units, as parts of the Martimo Formation, is $1.91 \mathrm{Ga}$ (Ranta et al., 2015b). A minimum age for all supracrustal rocks of the Peräpohja belt is given by the emplacement of ca. $1.88 \mathrm{Ga}$ synorogenic monzonite intrusions of the Haaparanta Series (Perttunen \& Vaasjoki, 2001).

The Peräpohja belt has undergone multiple deformation events during the Svecofennian orogeny between $-1.9-1.8$ Ga. Previously, three deformation stages have been identified in the Peräpohja belt (Kyläkoski et al., 2012, and references therein). However, Lahtinen et al. (2015) described up to five deformation stages in the youngest metasedimentary formation of the Peräpohja belt. According to that study, the earliest deformation stage D1 $(\leq 1.91 \mathrm{Ga})$ generated NS-trending fabric and recumbent folds due to the east-directed thin-skinned thrusting. NS shortening in the D2 stage (1.90-1.89 Ga) produced EW-trending folds and pervasive, steeply dipping foliation. The D3 stage $(1.88-1.87 \mathrm{Ga})$ is represented by NNW- and WNW-trending, heterogeneously developed structural trends. Traces of D4 deformation (1.83-1.81 Ga) are most prominently seen in the aeromagnetic images as NNE-lineaments. The last deformations stage (D5, $1.79-1.77 \mathrm{Ga}$ ) is characterized by WSW-shortening. Molnár et al. (2017a) presented U-Pb uraninite and Re-Os molybdenite ages for hydrothermal processes and demonstrated that the radiometric ages for the 


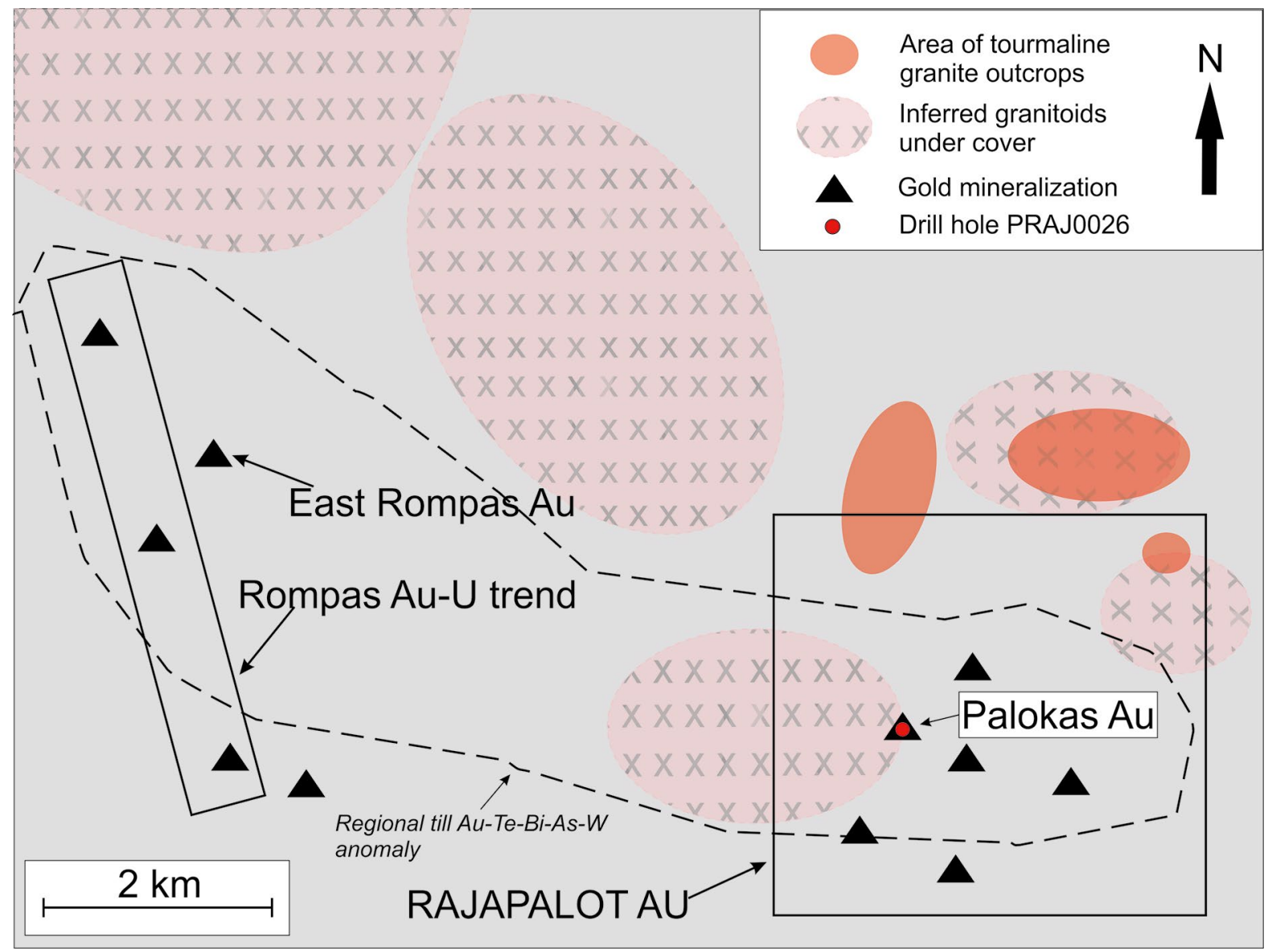

Figure 2. Schematic geological map of the Rompas-Rajapalot area, showing the presence of inferred granitoids below the surface (data from Mawson Resources Ltd.), areas where tourmaline granite outcrops are observed and the gold occurrences. The dashed line marks the area with anomalous abundances of $\mathrm{Au}, \mathrm{Bi}$ and Te in till (data from Mawson Resources Ltd.)

multiple hydrothermal events are in agreement with the ages of the major tectonic, metamorphic, and some magmatic events in the Rompas-Rajapalot area.

The metamorphic grade in the Peräpohja belt is variable, ranging from greenschist facies in the south to amphibolite facies in the north (Hölttä \& Heilimo, 2017). In the tectonized contact zone between the Peräpohja belt and Central Lapland granitoid complex, the rocks are locally migmatized. Rims of zircon grains from a migmatitic mica gneiss sample gave an age of around $1.8 \mathrm{Ga}$, which was interpreted by Ranta et al. (2015b) to correspond to the timing of the migmatization. Furthermore, the obtained Sm-Nd garnet-whole rock isochron age of $\sim 1.75 \mathrm{Ga}$ (Ranta et al., 2015b) is considered to represent the time of cooling of the crust down to $700-600{ }^{\circ} \mathrm{C}$ (i.e., the closure temperature of the $\mathrm{Sm}-\mathrm{Nd}$ isotope system in garnet; Mezger et al., 1992; Hensen \&Zhou, 1995).

Three different age groups are known among the Paleoproterozoic granitoids in the Peräpohja belt (Fig. 1): (1) $1.99 \mathrm{Ga}$, represented by the deformed porphyritic Kierovaara granite (Ranta et al., 2015b), (2) synorogenic 1.89-1.86 Ga Haaparanta Suite monzonitic plutons (Perttunen \& Vaasjoki, 2001), and (3) late- to post-orogenic 1.791.77 Ga pegmatitic, often tourmaline-rich granites (Lauerma, 1982; Ranta et al., 2015b). 


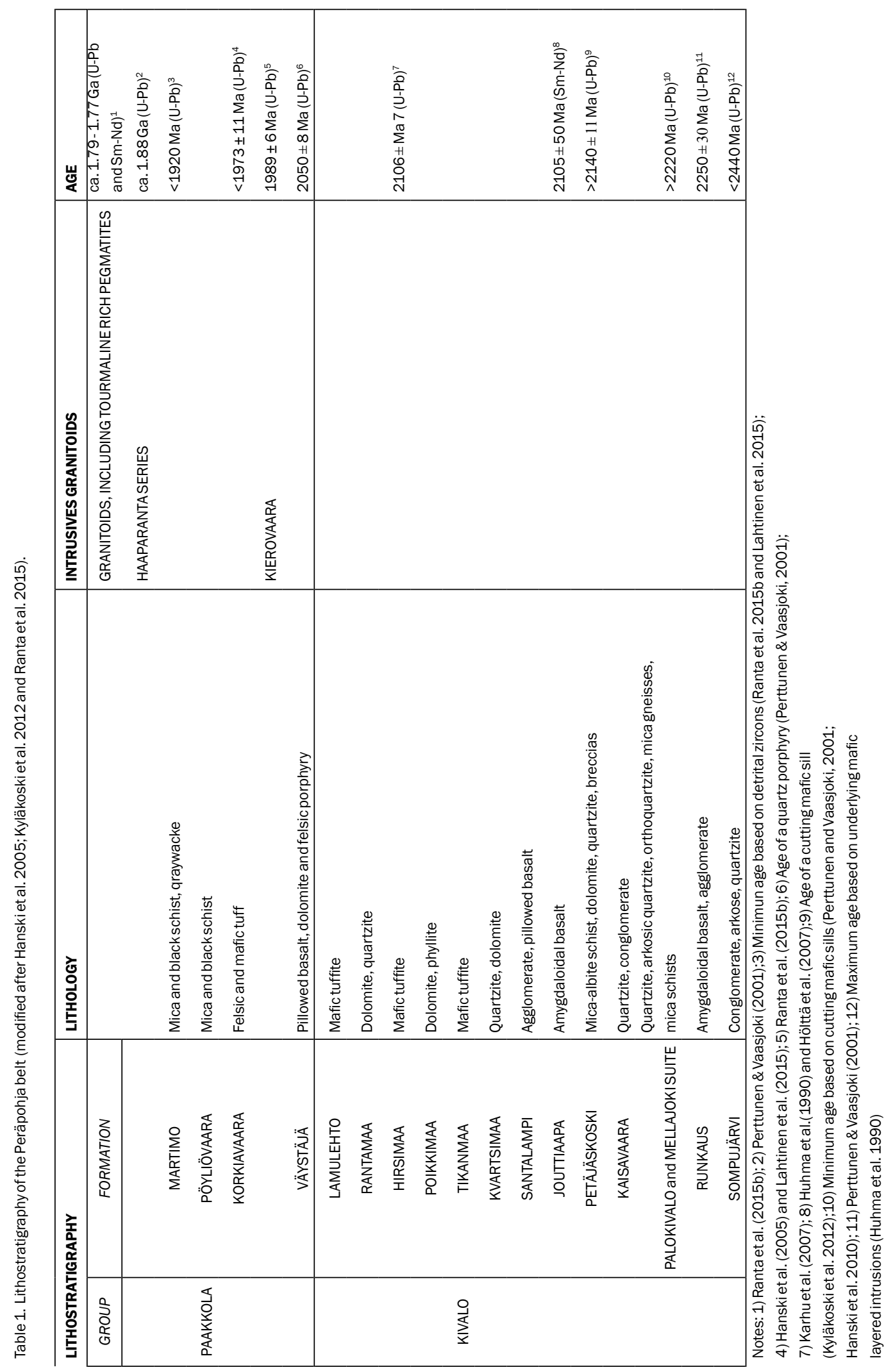




\section{Research methods}

\subsection{Petrography}

Samples for petrographic studies were chosen from Palokas Au prospect drill core. Polished thin sections were made in Thin Section Lab in Nancy, France, and studied using polarized transmittedand reflected-light microscopy.

\subsection{Electron probe microanalysis}

Major element compositions of minerals were determined using a JEOL JXA 8200 electron microprobe at the Center of Microscopy and Nanotechnology, University of Oulu. Analyses were performed with a beam current of $15 \mathrm{nA}$ and accelerating voltage of $15 \mathrm{kV}$. The counting times were set at $10 \mathrm{~s}$ and $5 \mathrm{~s}$ for the peak and background, respectively. Standards and detection limits during analyses of different mineral species are listed in the Electronic Appendix A.

\subsection{Determination of trace element composition of tourmaline by LA-SC-ICP-MS analysis}

Trace elements, especially the REE in tourmaline, provide important information on the environment of tourmaline formation (e.g., Yavuz et al., 2011; Hazarika et al., 2015; Kalliomäki et al., 2017). Laser ablation single collector inductively coupled plasma mass spectrometry (LA-SC-ICP-MS) was applied to measure REE contents of tourmaline using a $\mathrm{Nu}$ AttoM SC-ICP-MS instrument (Nu Instruments Ltd., Wrexham, UK) connected to an Analyte $193 \mathrm{ArF}$ laser ablation system (Photon Machines, San Diego, USA) at the Geological Survey of Finland (GTK). The laser was run at a pulse frequency of $10 \mathrm{~Hz}$ and a pulse energy of $3 \mathrm{~mJ}$ at $50 \%$ attenuation to produce an energy flux of $4.68 \mathrm{~J} / \mathrm{cm}^{2}$ on the sample surface with a $50 \mu \mathrm{m}$ spot size. The laser was automatically switched on for $60 s$ for signal acquisition and then off for $20 s$ for background level measurements. Analyses were conducted using time-resolved analysis (TRA) with continuous acquisition of data for each set of points (2 standards, 10 unknown glasses, 2 quality control standards). Synthetic NIST SRM 610 glass (concentrations reported in Jochum et al., 2011), tourmaline schorl standard (Dyar et al., 2001), and

${ }^{29} \mathrm{Si}$ were used as external and internal standards, respectively, for the quantification of the mineral composition. The measurements were performed over 45 elements at low resolution $(\Delta M / M=300)$ using the fast scanning mode. Data reduction was carried out using the software GLITTER ${ }^{\mathrm{TM}}$, which allows the baseline subtraction, the integration of the signal over a selected time resolve area, and the quantification using known concentrations of the external and internal standards.

\subsection{Fluid inclusion studies}

Quartz, carbonates, or other transparent hydrothermal minerals are generally the most common targets of fluid inclusion studies. However, in metamorphic terrains, quartz and carbonate are usually recrystallized or deformed and thus their fluid inclusions are often re-equilibrated. Alternatively, the presence of a large amount of secondary fluid inclusions obscures the recognition of those inclusions which could be related to the ore-forming or other processes under study. In the Palokas area, tourmaline is a common hydrothermal mineral in the veins and alteration zones with gold. Tourmaline is more resistant against mechanical and chemical alteration compared to quartz and carbonates, and, thus, it usually contains limited amounts of secondary fluid inclusions. Moreover, the common color zoning of this mineral helps in identification of primary fluid inclusions by petrographic methods.

Fluid inclusion petrography of tourmaline was performed in 80 - to 120 - $\mu \mathrm{m}$-thick, doublepolished thin sections under a polarizing microscope using up to $1000 \mathrm{x}$ optical magnification. Petrographic studies were targeted to determine the origin of fluid inclusions (e.g., primary, 
pseudosecondary, secondary, unknown; Roedder, 1984), as well as their phase compositions and degree of filling (e.g., estimated volume of the vapor phase compared to the total volume of fluid inclusions) at room temperature.

Conventional microthermometry analyses were performed by means of a LINKAM MDSG 600 type equipment using a 100x long-working distance objective at the Geological Survey of Finland, Espoo. The equipment calibration was performed using synthetic $\mathrm{CO}_{2}-\mathrm{H}_{2} \mathrm{O}$ and $\mathrm{H}_{2} \mathrm{O}$ inclusions. The analytical precision was $0.1{ }^{\circ} \mathrm{C}$ during the freezing runs and $1{ }^{\circ} \mathrm{C}$ during the homogenization experiments.

Raman analyses for determination of the volatile contents of fluid inclusions were completed by means of a Horiba JobinYvon LabRAM 800type high-resolution Raman microspectrometer supported by a Linkam THMS600 heating-freezing stage at the Eötvös Loránd University, Budapest, Hungary. The equipment is a dispersive, edge filterbased system equipped with a charge-coupled device (CCD) detector thermoelectrically cooled down to $-70{ }^{\circ} \mathrm{C}$. The confocal pinhole was set at $100 \mu \mathrm{m}$ and a 1800 grooves $/ \mathrm{mm}$ spectrograph grating was used, and the $532-\mathrm{nm}$ emission of a Nd-YAG laser was employed for excitation. Data were collected using 2 sets of 200-300 s acquisition. Spectra were collected at room temperature in most cases, but fluid inclusions showing liquid and vapor $\mathrm{CO}_{2}$ at room temperature were heated above the homogenization temperature of the $\mathrm{CO}_{2}$ phase prior to recording the Raman spectra.

\subsection{Whole-rock analysis}

The whole-rock major and trace element analyses were performed by the ALS Laboratories, Finland, using the ALS complete characterization package CCP-PKG01 (ALS Global, 2017). Major elements and the trace elements $\mathrm{Ag}, \mathrm{Cd}, \mathrm{Co}, \mathrm{Cu}, \mathrm{Li}, \mathrm{Mo}, \mathrm{Ni}$, $\mathrm{Pb}, \mathrm{Sc}$, and $\mathrm{Zn}$ were determined by ICP-AES, while $\mathrm{Ba}, \mathrm{Ce}, \mathrm{Cr}, \mathrm{Cs}, \mathrm{Dy}, \mathrm{Er}, \mathrm{Eu}, \mathrm{Ga}, \mathrm{Gd}, \mathrm{Ge}, \mathrm{Hf}, \mathrm{Ho}$, La, Lu Nb, Nd, Pr, Rb, Sm, Sn, Sr, Ta, Tb, Th, Tm, U, V, W, Y, Yb, Zr, As, Bi, Hg, In, Re, Sb, Se, Te, and
Tl were determined by ICP-MS. Total C and total $S$ were measured by a LECO analyzer. Detection limits and analytical ranges for each analyzed element are listed in the Electronic Appendix B.

\subsection{Geostatistics}

Multivariate statistical analysis of the geochemical database of the exploration drill core was performed in order to determine the association of elements in the gold mineralization at Palokas. These analytical data were obtained from Mawson Resources Ltd. The analyses of samples consisting of 1-m-long drill core split in half ( $26 \mathrm{~mm}$ diameter) were performed by ALS laboratory in Finland using the ALS package ME-MS61 (ALS Global, 2017). The components $\mathrm{Mg}, \mathrm{K}, \mathrm{Ca}, \mathrm{Na}, \mathrm{Al}, \mathrm{Fe}, \mathrm{Mn}, \mathrm{Cr}, \mathrm{Ba}, \mathrm{Au}, \mathrm{Pb}, \mathrm{U}, \mathrm{Ag}$, As, Be, Bi, Ce, Co, Cs, Cu, Ga, La, Li, Mo, Nb, Ni, $\mathrm{Rb}, \mathrm{Se}, \mathrm{Te}, \mathrm{Th}, \mathrm{V}, \mathrm{W}, \mathrm{Y}, \mathrm{Zn}, \mathrm{Zr}$, and Sr were involved in the geostatistical calculations.

Statistical methods for establishing groups and correlations in large geochemical datasets require a normal distribution of the concentration values. Since geochemical data usually do not follow a normal distribution, transformation of data into a logarithmic form before applying normal parametric tests is a common approach. However, Reimann \& Filzmoser (2000) showed that geochemical data follow neither a normal, nor a lognormal distribution and, hence, the use of normal parametric tests will lead to biased results in most cases.

The Pearson's product-moment correlation coefficient (R), which measures the strength and direction of a linear relationship between two variables, is commonly used for assessing the statistical relationship between two or more variables (e.g., Reimann et al., 2008). However, the presence of outliers will influence Pearson's $\mathrm{R}$ values and thus could yield a biased outcome. In order to obtain meaningful statistical results, one has to use robust or non-parametric methods in addition to a simple exploratory data analysis (e.g., scatter diagrams, box-plots etc.). The Spearman's correlation coefficient and Kendall rank correlation 
coefficient belong to non-parametric methods, which do not require normally distributed data and the presence of outliers do not affect the results in the same way, as in Pearson's correlation (e.g., Reimann et al., 2008) and, thus, they are used in this study.

\section{Results}

\subsection{Observations on geology, petrology and mineralogy of the Palokas gold occurrence}

The Rajapalot area, which encloses the Palokas gold occurrence, is located close to the northern margin of the Peräpohja belt. The lithology of the area is variable, comprising quartzites and unspecified albitized metasediments, pelitic metasediments, calcsilicate-albite rocks, cordierite-orthoamphibole rocks, schists rich in carbonaceous material and Fe-sulfides (mainly pyrite and pyrrhotite), and mafic rocks of both intrusive and volcanic origin. In addition to these rock types, intervals of cordieriteorthoamphibole rocks with abundant talc have been recognized in the drill core. Due to the scarcity of outcrops and a thick glaciogenic till cover in the area, the relationships between the rock units are not yet fully understood and, hence, a proper geological map is still to be compiled. The following description of the rock types is based on drill core and thin section observations. The petrographic study focused on the cordierite-orthoamphibole rocks and interlayered calcsilicate-albite rocks, as these are the dominant host rocks of gold in drill core from the Palokas occurrence.

\subsubsection{Cordierite-orthoamphibole rocks}

Cordierite-orthoamphibole rocks have been encountered in drill core (Fig. 3) with up to few tens of meters in apparent thickness. However, the true thickness of the rock unit is still unclear. The rocks are moderately foliated and gray in color and generally contain up to $5 \%$ pyrrhotite (Figs. $4 \mathrm{a}$ and 4b). A characteristic feature is the presence of pale green to white, bladed, weakly oriented amphibole (ranging in size between $<0.5$ and $5 \mathrm{~mm}$ ), which locally forms radially growing aggregates. The matrix is composed of fine- to medium-grained $(<1-3 \mathrm{~mm})$ plagioclase and biotite. Medium- to coarse-grained, poikiloblastic cordierite and orthoamphibole occur as porphyroblasts (Figs. 5a and $5 \mathrm{~b}$ ). Locally, cummingtonite is found in the cores of anthophyllite grains (Fig. 5b), indicating a retrograde reaction, where cummingtonite is consumed during the anthophyllite formation (e.g., Elliott-Meadows et al., 2000). Biotite is present in various proportions in the matrix, both as coarsegrained, non-foliated grains and fine- to mediumgrained crystals, following the foliation. Locally, biotite shows retrograde chloritization. The main type of sulfide is pyrrhotite. One textural type of pyrrhotite occurs in foliated and folded bands, which are elongated parallel to the foliation (Figs. 4a and 5c) and locally show complex folding patterns indicating pre- and/or syn-metamorphic growth (Mawson Resources Ltd., unpublished report). Pyrrhotite is also present as a relatively late mineral filling, brecciating and cementing the tourmalinequartz veins (Figs. 4c and 5f). Moreover, abundant pyrrhotite is also present in the heavily chloritized intervals (Fig. 5d). The latter two pyrrhotite textures seem to represent a later event compared to the pyrrhotite showing complex folding within the cordierite-orthoamphibole host rock, as they do not show folding and deformation textures. These later pyrrhotite-rich precipitates also contain pyrite, chalcopyrite, scheelite, cobaltite, Co-pentlandite, Se-rich tetradymite, native bismuth, molybdenite, and native gold. In this study, occurrence of gold in the foliated and deformed pyrrhotite was not observed, but other studies have found indications of it (Mawson Resources Ltd., unpublished).

The main oxide mineral is ilmenite forming dissemination in the cordierite-orthoamphibole rock. Coarse-grained magnetite, most probably hydrothermal in origin, is also abundant locally in this rock. Sporadic dissemination of fine- 


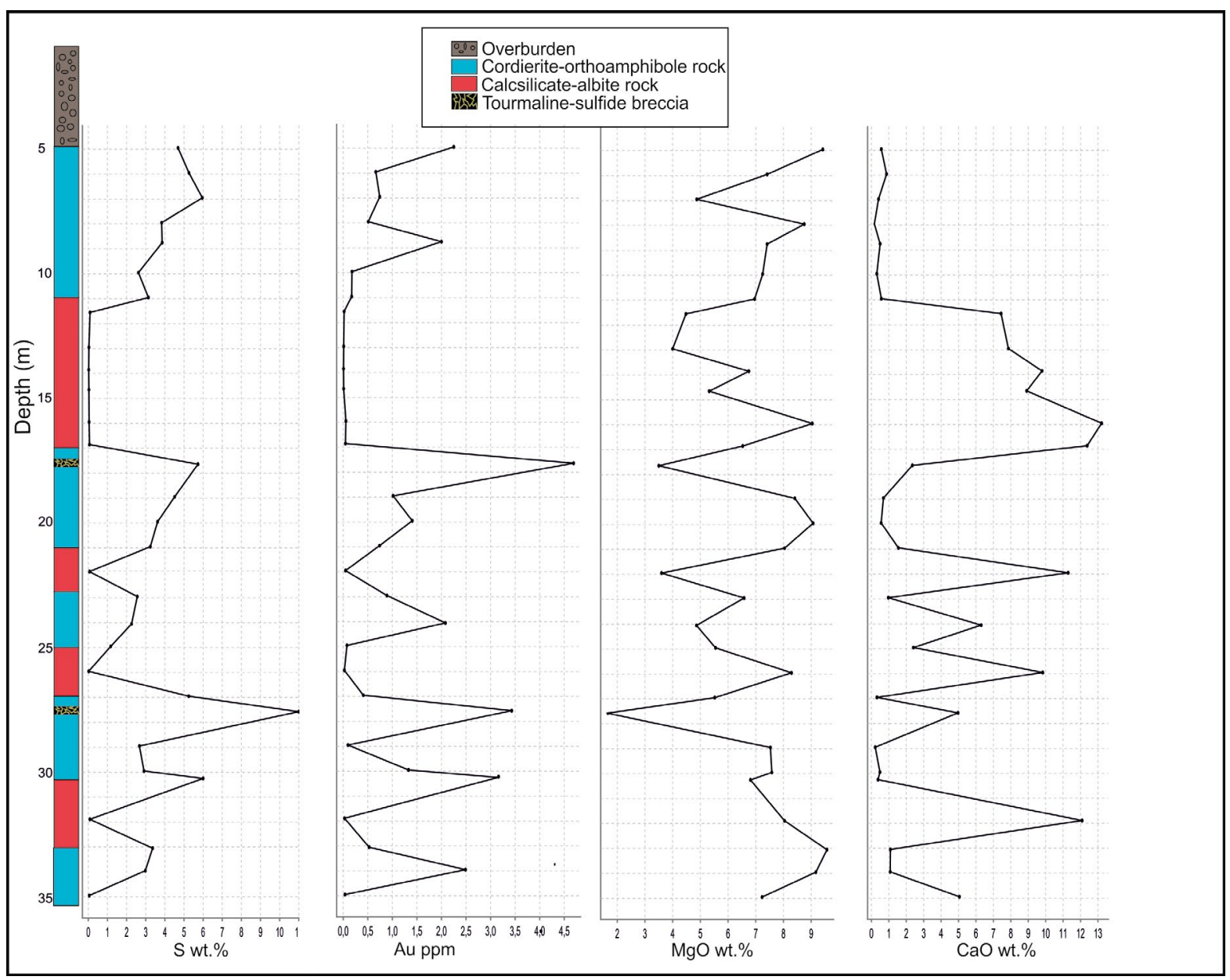

Figure 3. Downhole drillcore log (drillhole PRAJ0026) showing representative element and oxide concentrations distinguishing the gold-bearing cordierite-orthoamphibole intervals.

grained uraninite is also present in the cordieriteorthoamphibole rocks. Uraninite grains are generally surrounded by radioactive damage halos. Tourmaline is an accessory mineral in the cordieriteorthoamphibole rock but a major constituent in the tourmaline-sulfide-quartz veins (Figs. $4 \mathrm{c}$ and $5 \mathrm{~d})$. These veins are up to $-30 \mathrm{~cm}$ in thickness and clearly cut the foliation of the rock. Chlorite is a common alteration product of amphibole and biotite at the vein margins, locally completely replacing the minerals of the host rock up to meters from the veins (Figs. 4d and 5c). Other accessory minerals in the cordierite-orthoamphibole rocks include cummingtonite, garnet, apatite, quartz, sericite, and zircon. In the tourmaline-sulfidequartz breccias, Se-rich tetradymite, native bismuth, molybdenite, native gold, and apatite are also found as accessory phases.

\subsubsection{Calcsilicate-albite rocks}

The calcsilicate-albite rock units form interlayers within the cordierite-orthoamphibole rocks and mafic units (amphibolites). The former are probably of volcanic origin, as no clear intrusive contacts have been observed at Palokas. The contacts with the mafic rocks are often sharp and those with the cordierite-orthoamphibole rocks are relatively 


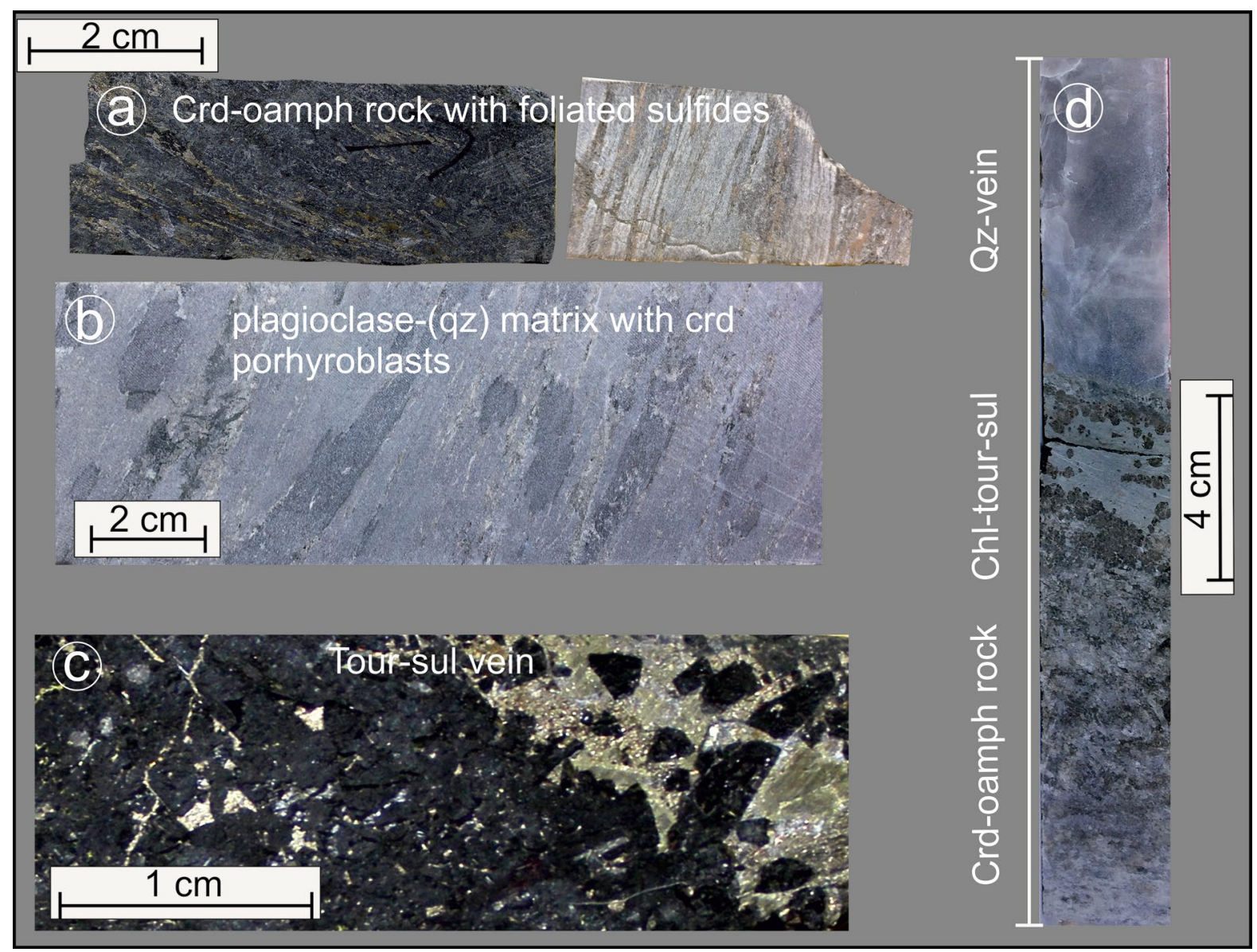

Figure 4. Representative drillcore samples of cordierite-orthoamphibole rock at Palokas. a) Cordierite-orthoamphibole rock with sulfides. b) Cordierite-orthoamphibole rock with elongated cordierite porphyroblasts in a plagioclase matrix (dark elongated domains). Pale green, fine-grained minerals are orthoamphiboles. c) Tourmaline-sulfide veins. d) Late quartz veins with chlorite-tourmaline margins.

sharp as well, mostly noticeably with a change of the amphibole minerals from $\mathrm{Ca}-\mathrm{Fe}-\mathrm{Mg}$ amphiboles (tremolite-actinolite) to Ca-poor Fe- Mg- Mn- $\mathrm{Li}$ amphiboles (e.g., anthophyllite). The shift can be seen as the change of the crystal habit and color of amphibole and incoming of diopside. Also, in many cases, the color of the whole rock changes from gray to red and green. However, transitional zones containing both Ca-bearing and Ca-poor amphiboles are also present.

The color of the calcsilicate-albite rock varies from light red to gray (Figs. 6a and 6b). In hand specimen, green patches with a variable size (up to several centimeters), consisting of amphibole of the tremolite-actinolite series and diopside, are observed throughout. The matrix of albitite is composed of untwinned, granoblastic plagioclase varying from albite to andesine in composition $\left(\mathrm{An}_{3-35}\right.$; Figs. $5 \mathrm{~g}$ and $\left.5 \mathrm{~h}\right)$. The amount of quartz in the matrix is generally under $5 \%$. Porphyroblasts of tremolite-actinolite \pm diopside are present in various proportions; locally, tremolite replaces diopside (Figs. 5g and 5h). Titanite and calcite are common and chlorite and hematite are less common accessory minerals. Sulfides, dominantly pyrrhotite with locally also pyrite, are disseminated and occur sporadically, falling generally below $1 \%$ in abundance. 

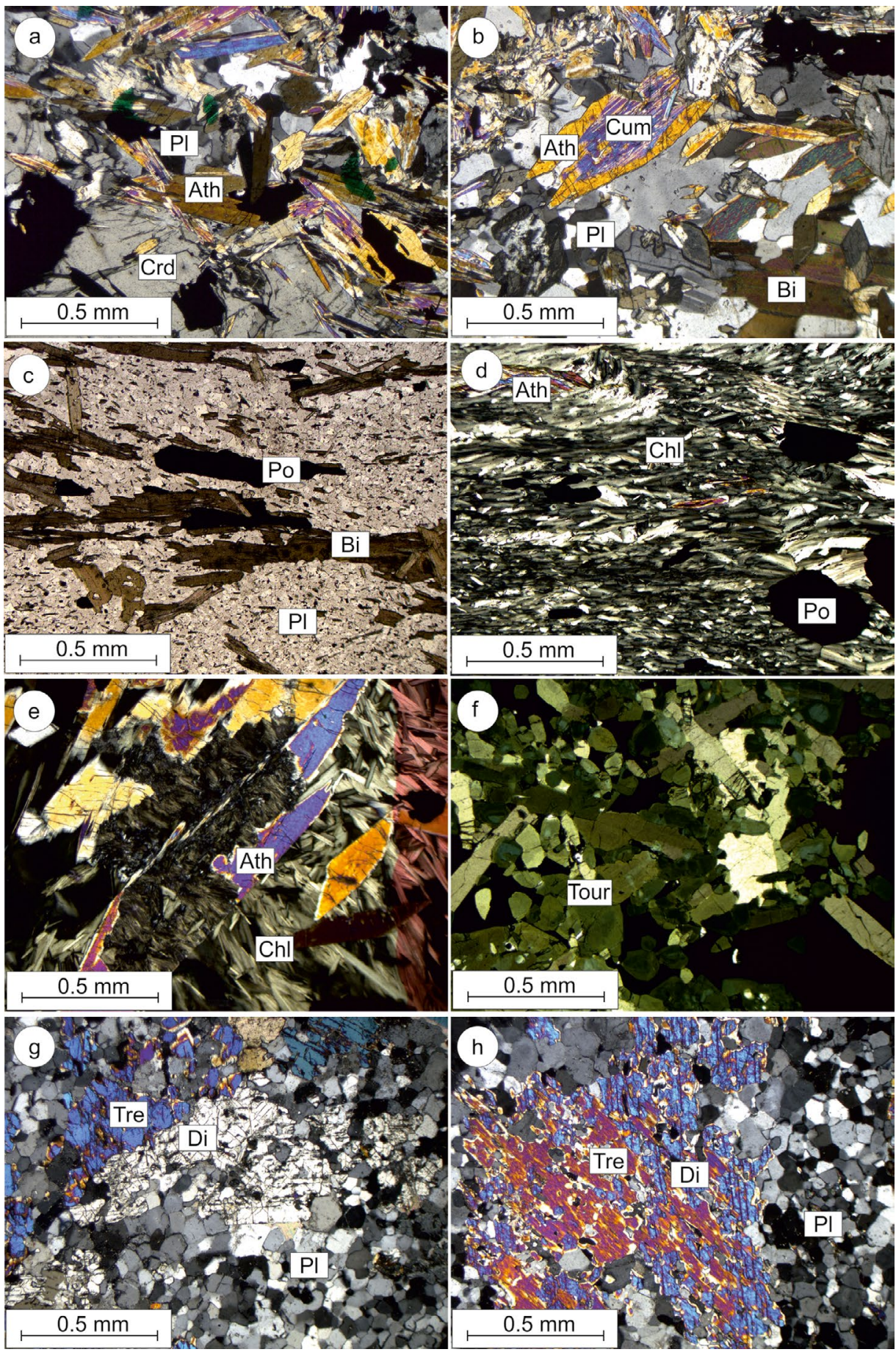

Figure 5. Photomicrographs of cordierite-orthoamphibole rocks and calcsilicate-albite rocks. a) Cordierite-orthoamphibole rock. b) Cordierite-orthoamphibole rock with an amphibole grain having a cummingtonite (clinoamphibole) core and anthophyllite rims. c) Foliated cordierite-orthoamphibole rock with pyrrhotite parallel to the foliation. d) Heavily chloritized cordierite-orthoamphibole interval with pyrrhotite. e) Chloritized cordierite-orthoamphibole rock. f) Late-stage tourmaline-sulfide vein. g) and h) Calcsilicate-albite rock showing a diopside porphyroblast partly altered to tremolite in a

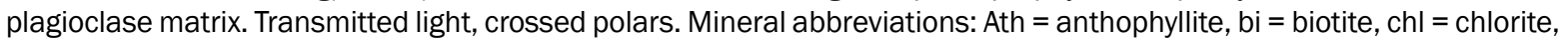
$\mathrm{crd}=$ cordierite, cum $=$ cummingtonite, $\mathrm{di}=$ diopside, $\mathrm{pl}=$ plagioclase, $\mathrm{po}=$ pyrrhotite , tre $=$ tremolite . 


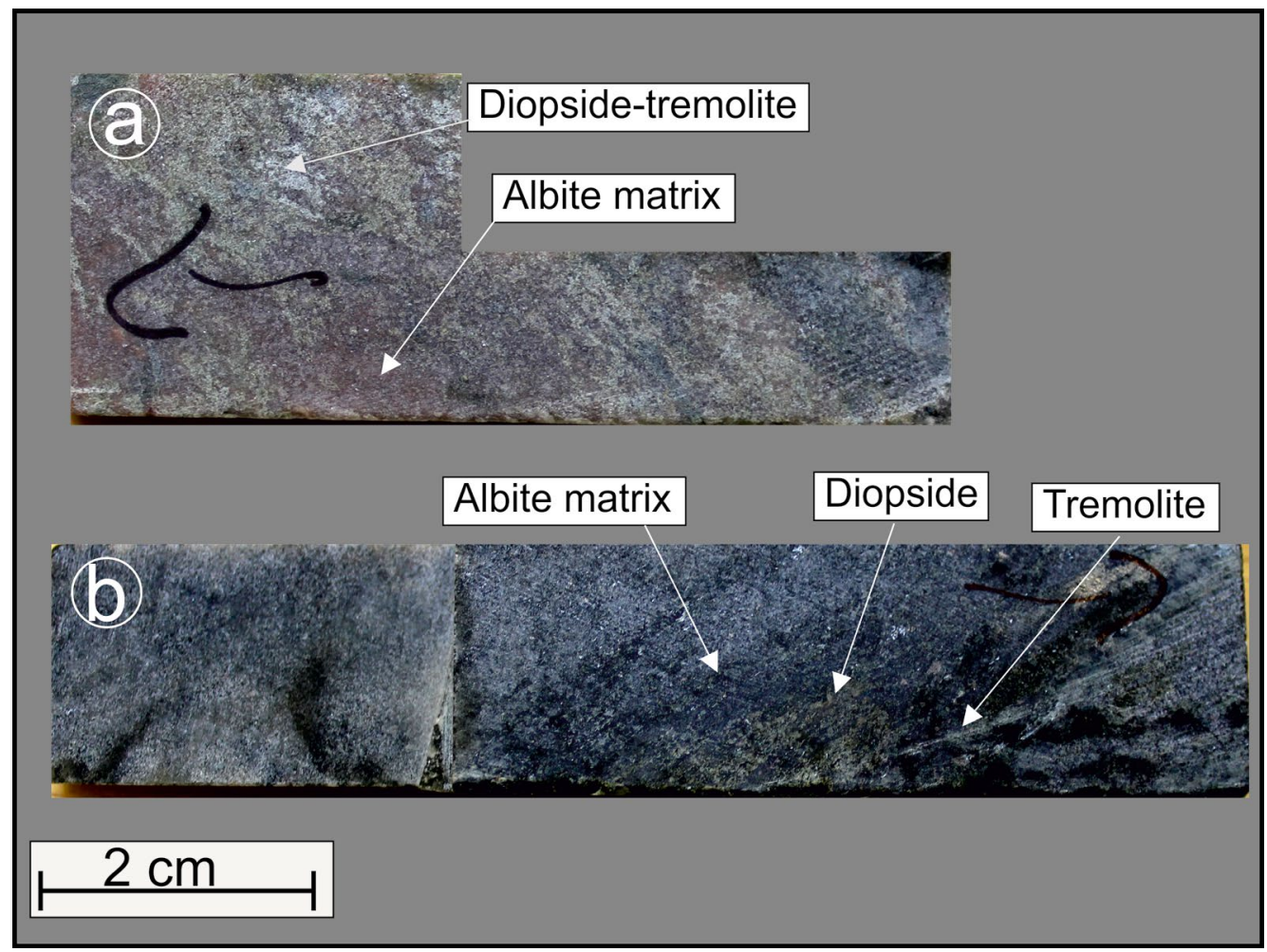

Figure 6. Representative drillcore samples of calcsilicate-albite rocks at Palokas. a) Reddish albitite with green diopside-tremolite. b) Grayish albitite with greenish diopside and tremolite.

\subsubsection{Occurrences of native gold and associated minerals}

Native gold occurs in the cordierite-orthoamphibole rock unit as single grains within the rockforming silicates (Fig. 7a) and in fractures of tourmaline in the late tourmaline-sulfide-quartz veins (Fig. 7b) (Ranta et al., 2017). Native gold grains between the silicates in the disseminated style seem to be not related to any late fractures and are generally coarser grained (up to $20 \mu \mathrm{m}$ ) than the gold in fractures of tourmaline-rich veins. Locally, fracture-related gold has been found outside of the tourmaline veins, within the chloritized intervals at the edges of pyrrhotite (Fig. 7c) or in late fractures together with Bi-Te-S-minerals (Fig. 7d). The common associated ore minerals in fractures are Se-tetradymite, molybdenite, pyrrhotite, chalco- pyrite, and native bismuth (Fig. 7b), which are different from the sulfide mineral association of coarser gold located between silicates which mainly is composed of pyrrhotite with minor pyrite and chalcopyrite.

\subsection{Whole-rock geochemistry of cordierite-orthoamphibole rocks and calcsilicate-albite rocks}

Table 2 presents average chemical compositions of the gold-bearing cordierite-amphibole rocks and interlayered, barren calcsilicate-albite rocks. Figures 8-9 and 14-16 show various chemical diagrams with comparative data from other rock formations of the Peräpohja belt and literature data for other cordierite-orthoamphibole-bearing rocks. 

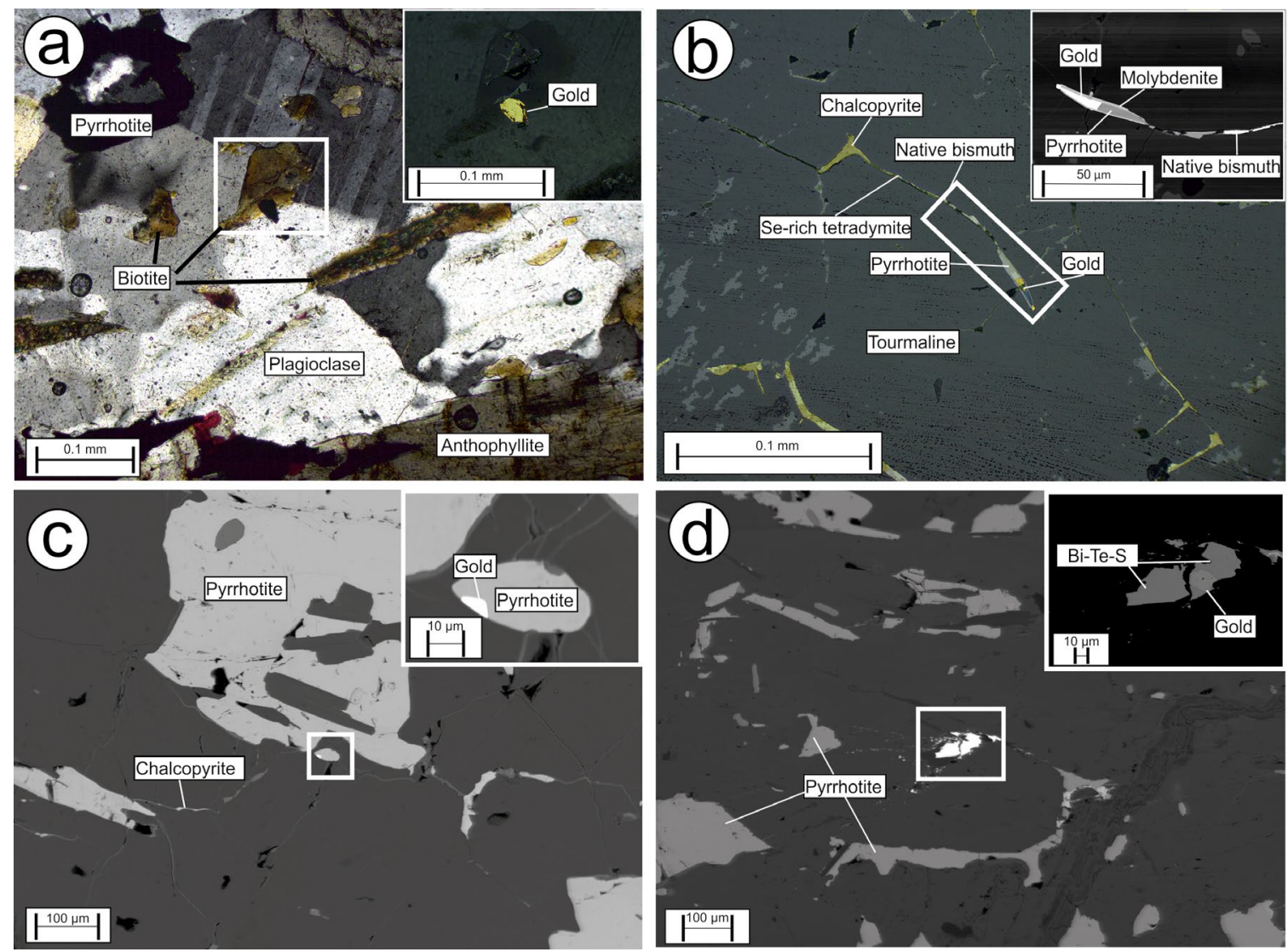

Figure 7. Native gold grains at Palokas. a) Photomicrograph of a native gold grain between silicates (plagioclase and biotite). b) Back-scattered electron (BSE) image of gold in fractures of tourmaline together with ore minerals. The inset shows a back-scattered electron image of gold and associated pyrrhotite grains with molybdenite rims. c) BSE image of native gold in the edge of pyrrhotite in a highly chloritized cordierite-orthoamphibole rocks. d) BSE image of native gold with an associated Bi-Te-S-grain in fracture within highly chloritized interval.

\subsubsection{Cordierite-orthoamphibole rocks}

The $\mathrm{SiO}_{2}$ content shows a large range, from 25 to 65 wt. $\%$, with the lowest levels related to a high degree of chlorite and sulfide alteration. It has a negative correlations with $\mathrm{FeO}$ and $\mathrm{MgO}$ (Figs. $8 \mathrm{~b}$ and $8 \mathrm{c})$. The $\mathrm{CaO}$ content is generally less than $2 \mathrm{wt} . \%$. This is one of the most distinctive geochemical features of these rocks compared to the interlayered calcsilicate-albite rocks (Fig. 8g). One sample shows up to 6 wt. $\% \mathrm{CaO}$, which can be explained by a relatively high abundance of rounded, oscillatory-zoned plagioclase with anorthitic composition. The $\mathrm{Al}_{2} \mathrm{O}_{3}$ content varies from 8 to 18 wt. $\%$, with most samples falling between 10 and
14 wt.\% (Fig. 8a). The highest $\mathrm{Al}_{2} \mathrm{O}_{3}$ content is in the most chloritized samples. The $\mathrm{MgO}$ content spans a range from $4 \mathrm{wt} . \%$ to $13.5 \mathrm{wt} . \%$, increasing as the degree of chloritization increases (Fig. 8c). Most of the non-chloritized samples show an $\mathrm{MgO}$ content between 6 and 10 wt. $\%$. The $\mathrm{Na}_{2} \mathrm{O}$ content varies from less than $1 \mathrm{wt} . \%$ in the chloritized samples and up to $6 \mathrm{wt} . \%$ in non-chloritized samples (Fig. 8d).

Chondrite-normalized REE patterns and upper continental crust-normalized multi-element plots are presented in Figs. 9a and 9b. The REE patterns are moderately steep with high LREE abundances compared to HREE and prominent negative Eu anomalies $\left(\mathrm{Eu} / \mathrm{Eu}^{*}=0.20-0.81\right)$. For comparison, 


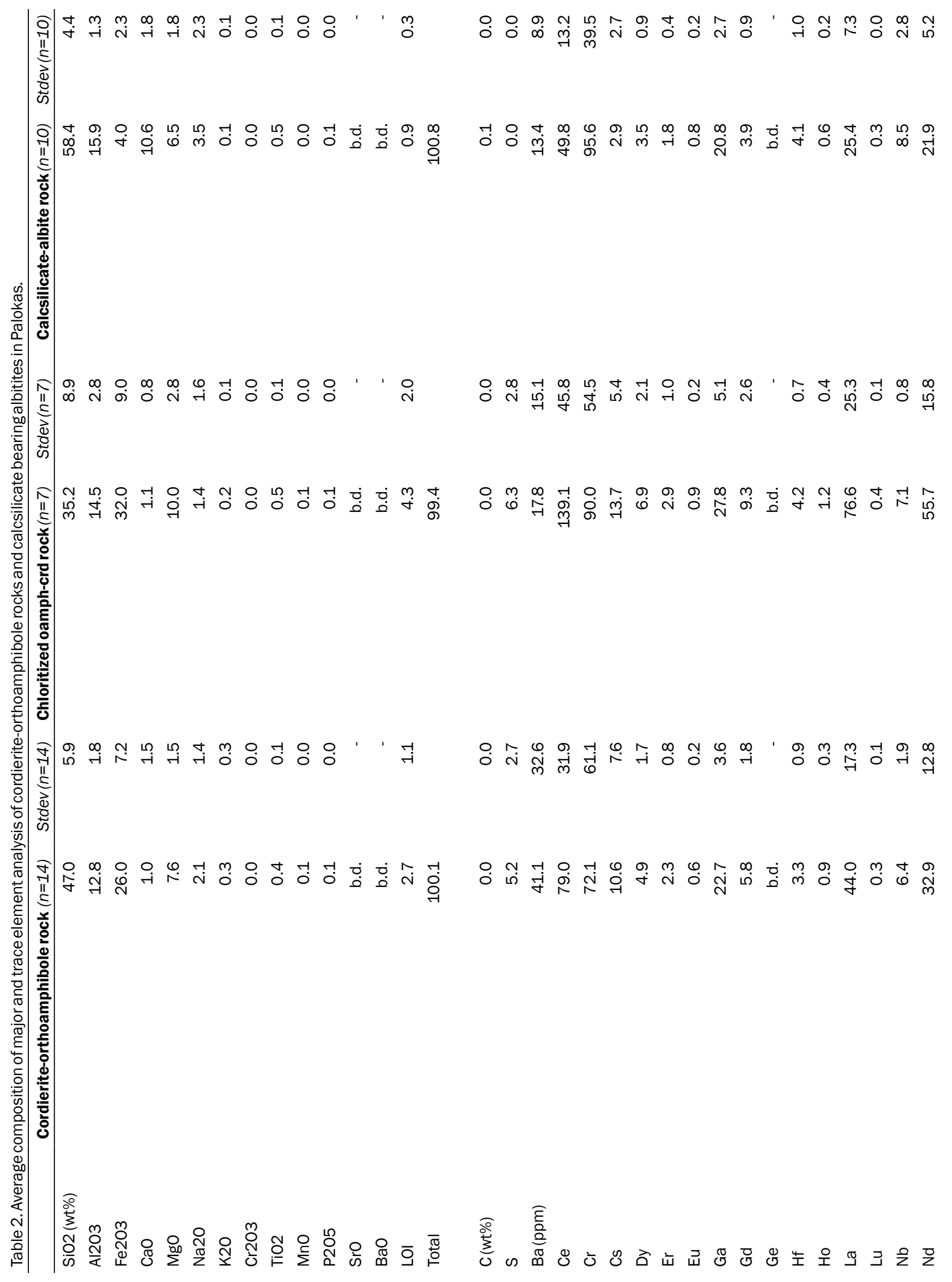




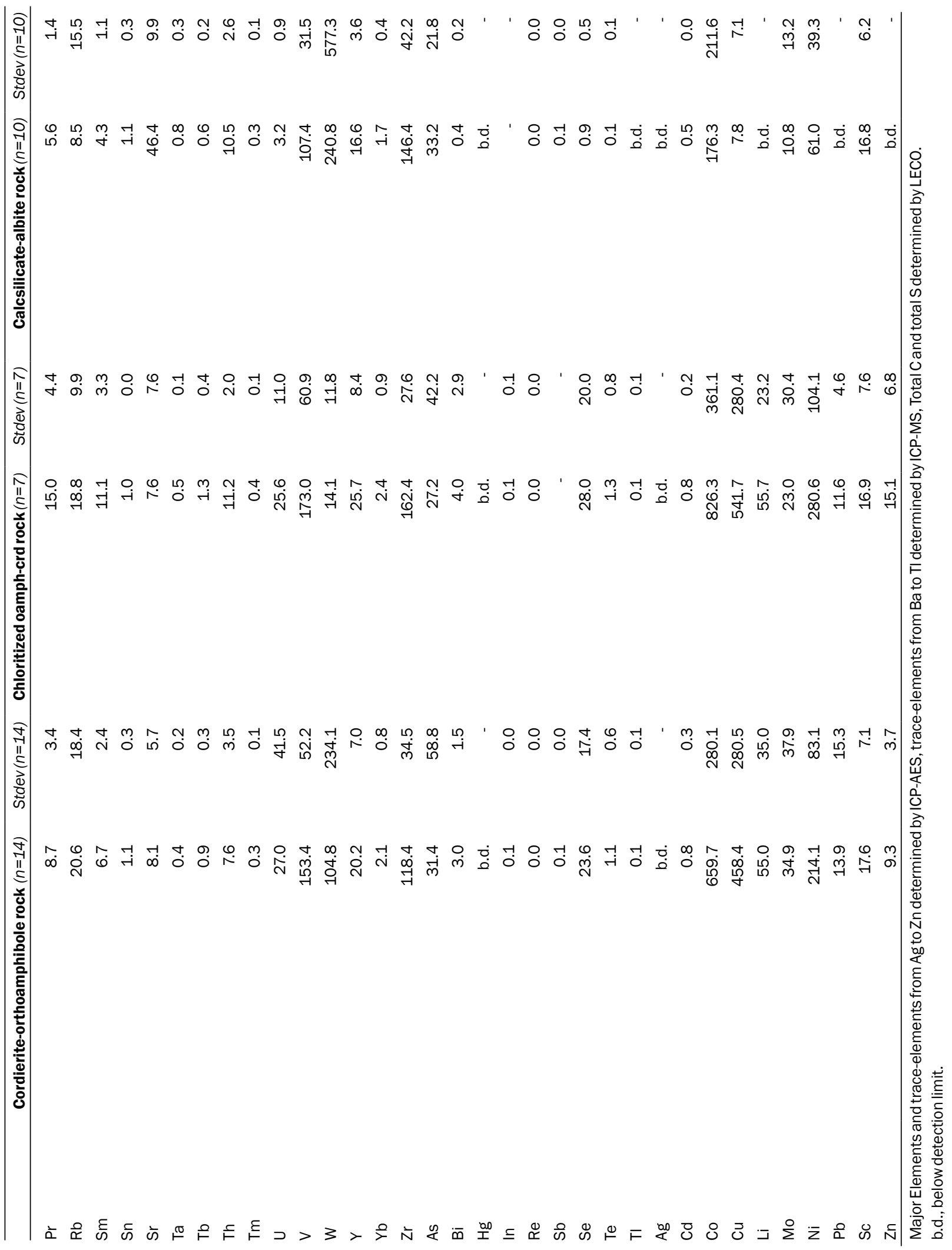




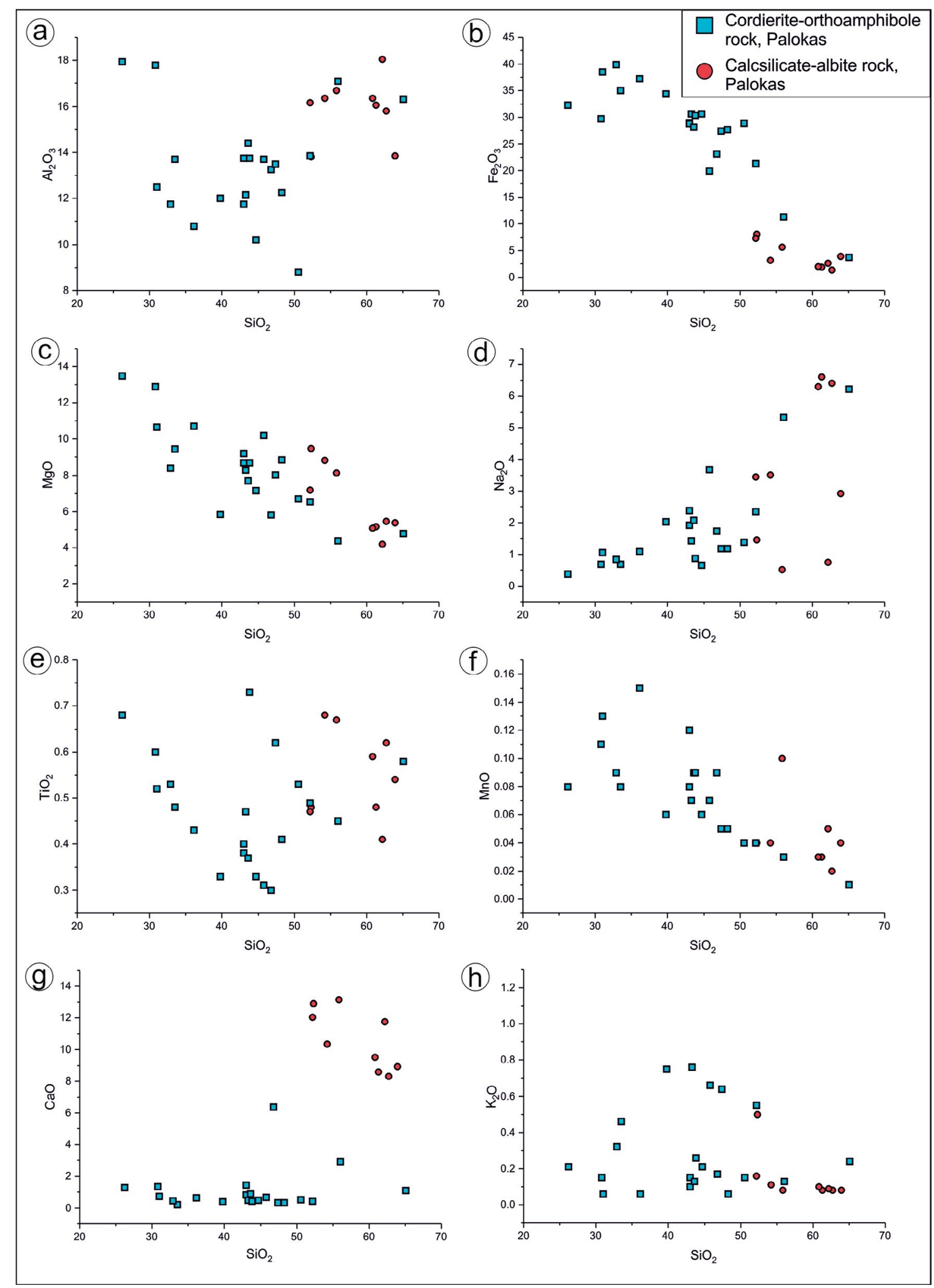

Figure 8. Harker plots for cordierite-orthoamphibole rocks and calcsilicate-albite rocks. 


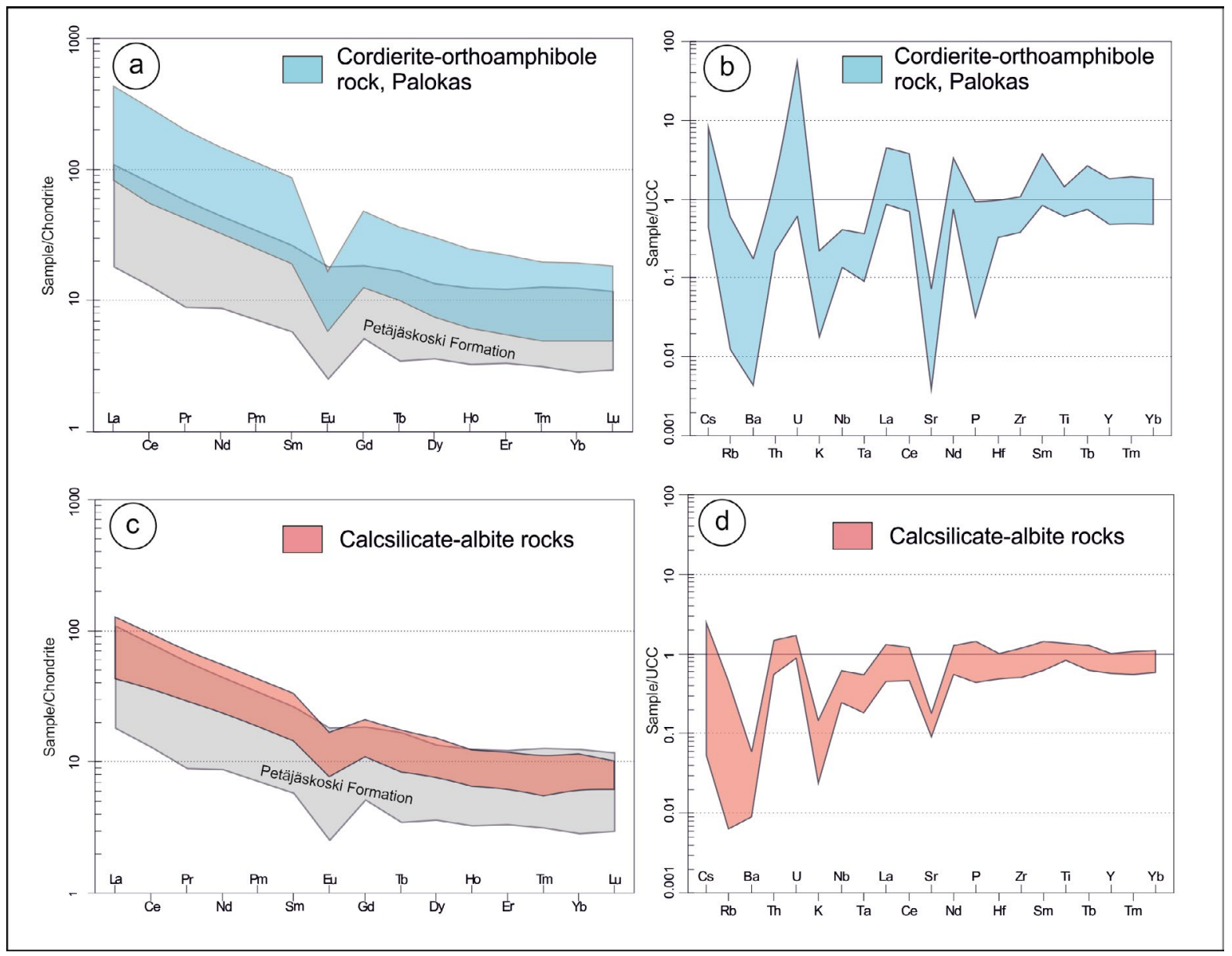

Figure 9. Chondrite-normalized REE patterns ( $a$ and $c$ ) and upper continental crust-normalized multi-element plots (b and d) for cordierite-orthoamphibole rocks and calcsilicate-albite rocks. REE data from the Petäjäskoski Formation are given for comparison (Kyläkoski et al., 2012). Chondrite normalization values are from Boynton (1984) and upper continental crust normalization values from Taylor \& McLennan (1995).

REE data from the Petäjäskoski Formation (Kyläkoski et al., 2012) illustrated in Figs. 9a and 9c, show a similar trend but lower abundances than in the cordierite-orthoamphibole rocks. The multielement patterns display clear positive $\mathrm{Cs}$ and $\mathrm{U}$ anomalies and negative $\mathrm{Ba}, \mathrm{K}, \mathrm{Sr}$, and $\mathrm{P}$ anomalies.

\subsubsection{Calcsilicate-albite rocks}

Calcsilicate-albite rocks show a narrower range in chemical compositions (Figs. 8a-h), reflecting the lack of significant post-metamorphic alteration. The $\mathrm{SiO}_{2}$ content ranges from 54 to 63 wt.\%.
$\mathrm{CaO}$ is notably higher than in the cordieriteorthoamphibole rocks (9-13 wt.\%) and $\mathrm{Al}_{2} \mathrm{O}_{3}$ varies between 14 and $17 \mathrm{wt} . \%$. The iron content is generally low $\left(<4\right.$ wt. $\left.\% \mathrm{FeO}_{\text {tor }}\right)$ but in the samples containing more calcsilicate minerals, it increases up to $8 \mathrm{wt} . \%$. The $\mathrm{K}_{2} \mathrm{O}$ content is low $(<0.1-$ 0.2 wt.\%) and $\mathrm{Na}_{2} \mathrm{O}$ varies from 0.5 up to almost $7 \mathrm{wt} . \%$, with the highest values corresponding to about $56 \%$ of modal albite.

Chondrite-normalized REE patterns (Figs. 9c and 9d) show a LREE enrichment and negative $\mathrm{Eu}$ anomalies (Eu/Eu* 0.22-0.81). The trends are similar to those of the cordierite-orthoamphibole 


\begin{tabular}{|c|c|c|}
\hline & Spearsman & Kendall's tau \\
\hline $\mathrm{Au}$ & 1 & 1 \\
\hline $\mathrm{Pb}$ & 0.476 & 0.337 \\
\hline U & 0.492 & 0.348 \\
\hline $\mathrm{Ag}$ & 0.619 & 0.468 \\
\hline As & 0.523 & 0.372 \\
\hline $\mathrm{Be}$ & -0.078 & -0.056 \\
\hline $\mathrm{Bi}$ & 0.662 & 0.501 \\
\hline $\mathrm{Ce}$ & 0.308 & 0.214 \\
\hline Co & 0.714 & 0.538 \\
\hline Cs & 0.289 & 0.203 \\
\hline $\mathrm{Cu}$ & 0.728 & 0.547 \\
\hline Ga & 0.349 & 0.251 \\
\hline La & 0.338 & 0.236 \\
\hline $\mathrm{Li}$ & 0.276 & 0.196 \\
\hline Mo & 0.627 & 0.458 \\
\hline $\mathrm{Nb}$ & 0.217 & 0.150 \\
\hline $\mathrm{Ni}$ & 0.407 & 0.294 \\
\hline $\mathrm{Rb}$ & 0.149 & 0.103 \\
\hline $\mathrm{Se}$ & 0.675 & 0.546 \\
\hline $\mathrm{Te}$ & 0.730 & 0.603 \\
\hline V & 0.187 & 0.127 \\
\hline W & 0.511 & 0.370 \\
\hline Y & -0.067 & -0.041 \\
\hline Zn & 0.233 & 0.165 \\
\hline $\mathrm{Sr}$ & -0.423 & -0.293 \\
\hline $\mathrm{Ca}$ & -0.346 & -0.239 \\
\hline $\mathrm{Fe}$ & 0.515 & 0.371 \\
\hline
\end{tabular}

p-value $<0.0001$ rocks and the Petäjäskoski Formation. Upper continental crust-normalized multi-element patterns show negative $\mathrm{Rb}, \mathrm{Ba}, \mathrm{K}$ and $\mathrm{Sr}$ anomalies. In contrast to the cordierite-orthoamphibole rocks, $\mathrm{Cs}$ and $\mathrm{U}$ do not show clear positive anomalies.

\subsubsection{Geostatistical analyses of trace element data from exploration drillcore}

Results of the statistical analyses of the drillcore data (Mawson Resources Ltd. unpublished data) from the Rajapalot area are listed in Table 3. Concentration of gold correlates strongly with
Te, Cu, Co, Se, Bi, Mo, and Ag ( $\rho=0.730-0.619)$ whereas moderate correlations are found with As, Fe, W $(\rho=0.523-0.511)$ and, to a lesser extent, with $\mathrm{U}, \mathrm{Pb}$, and $\mathrm{Ni}(\rho=0.492-0.407)$. Gold has the strongest negative correlations with respect to $\mathrm{Sr}$ and Ca. Kendall's Tau correlation coefficients are consistently lower, but show the same elemental correlations as Spearman's coefficients.

\subsection{Mineral chemistry in the cordierite-orthoamphibole rocks}

\subsubsection{Amphiboles and cordierite}

Amphibole compositions were classified using the Excel spreadsheet program of Locock (2014), following the IMA 2012 amphibole classification guidelines (Hawthorne et al., 2012). The majority of the analyzed orthoamphibole grains belong to the Fe-Mg-Mn amphibole subgroup and can be classified as anthophyllite and gedrite (Fig. 10a). The locally present clinoamphibole has variable composition corresponding to cummingtonite, edenite, or hornblende. Cordierite shows little variation in its major element composition, having molar $100 \mathrm{xMg} /(\mathrm{Mg}+\mathrm{Fe}+\mathrm{Mn})$ between 70.8 and 79.3 (avg. 76.8; $\mathrm{n}=13$ ).

\subsubsection{Plagioclase}

In the matrix of the cordierite-orthoamphibole rock, the composition of plagioclase varies from oligoclase to andesine $\left(\mathrm{An}_{21-39} ;\right.$ avg. $\left.\mathrm{An}_{31} ; \mathrm{n}=25\right)$. Locally, samples contain twinned plagioclase crystals with a highly anorthitic composition $\left(\mathrm{An}_{91-98} ;\right.$ Fig. 10d). Rounded plagioclase crystals with oscillatory zoning, which are generally found in intensively chloritized intervals, display reverse zoning, where crystals become more calcic towards their rims, ranging from anorthite to labradorite in composition (Fig. 10d). Also, rounded plagioclase crystals $\mathrm{An}_{60-70}$, without zoning, occur in the chlorite matrix. 


\subsubsection{Sheet silicates}

Biotite is relatively rich in magnesium, with its composition falling close to the biotite/ phlogopite boundary in the $\mathrm{Fe} /(\mathrm{Fe}+\mathrm{Mg})$ vs. $\mathrm{Al}_{\mathrm{IV}}$ diagram of Deer (1992) shown in Fig. 10b. A few of the analyzed biotite grains can be classified as phlogopite. Based on the ratio of $\mathrm{Ti} /(\mathrm{Mg} /(\mathrm{Mg}+\mathrm{Fe}))$, an average crystallization temperature of $520^{\circ} \mathrm{C}$ can be calculated for biotite according to the calibration by Henry et al. (2005). However, this should be taken as a rough estimate, since this biotite thermometer is calibrated to ilmenite- or rutile- and graphite-bearing peraluminous metapelites and the lack of the requisite mineral assemblage could lead to a minor to significant error in the temperature estimates (Henry et al., 2005).

Chlorite compositions are classified according to Hey (1954), based on the $\mathrm{Si}$ and $\mathrm{Fe}_{\text {tot }}$ contents (Fig. 10e). Most of the analyzed grains fall in the field of ripidolite, but few pycnochlorite and one diabantite compositions are also identified, where chlorite occurs as an alteration product of the amphibole. The $\mathrm{Fe} /(\mathrm{Fe}+\mathrm{Mg})$ ratios are between 0.22 and 0.47 (avg. $0.38 ; \mathrm{n}=75$ ).

\subsubsection{Tourmaline crystal chemistry and boron isotope composition}

Major- and trace element abundance data and boron isotope composition of tourmaline in the Palokas gold mineralization and in a tourmaline granite near the Palokas mineralization were published by Ranta et al. (2017). All tourmaline at Palokas belongs to the alkali group and can be classified as dravite (Fig. 10f). Based on the cation substitutions in the tourmaline structure, Ranta et al. (2017) proposed that the tourmaline in the tourmaline granite and the Palokas gold mineralization was formed in a reducing environment. Furthermore, the uniformity of the boron isotope signature within single tourmaline crystals and between all the analyzed samples, suggests that tourmaline from different rocks was formed in the same magmatic-hydrothermal system (Ranta et al., 2017).

The chondrite-normalized REE patterns of the tourmaline from the gold mineralized rocks (both vein type and host rock tourmaline) and from the granite partly overlap and show similar trends (Fig. 11). However, tourmaline from the gold mineralization has a total REE abundance of 5.5-14.2 ppm, whereas the total amount of REE in tourmaline from the granite is clearly lower, falling in the range of 0.9-5.2 ppm. Chondrite-normalized REE patterns show LREE-enriched trends, with the enrichment being lower in tourmaline from the granite. However, Eu shows a positive anomaly in tourmaline from the mineralization and a negative anomaly in tourmaline from the granite. Europium anomalies are used to fingerprint the redox state during magmatic and hydrothermal processes because of the di- and trivalent oxidation states of europium. A positive europium anomaly indicates incorporation of $\mathrm{Eu}^{2+}$ into the tourmaline, where it exists under reducing conditions. Furthermore, its stability increases with increasing temperature in hydrothermal fluids (e.g., Sverjensky, 1984; Haas et al., 1995). Overall, tourmaline from the granite located around $1 \mathrm{~km}$ north from the main Palokas occurrence and tourmaline from Palokas display similarities in REE patterns, though some differences exist. However, as noted in previous studies (e.g., Kalliomäki et al., 2017), the majorand trace element composition of tourmaline can be highly affected by interaction with local host rocks and, therefore, differences may exist between tourmalines in different host rocks even if the fluid source is the same.

\subsection{Fluid inclusions in tourmaline}

\subsubsection{Petrography}

Tourmaline from the gold-bearing veins contains relatively few, fracture-hosted secondary fluid inclusion trails. This is due to the resistant nature of tourmaline towards post-depositional processes 


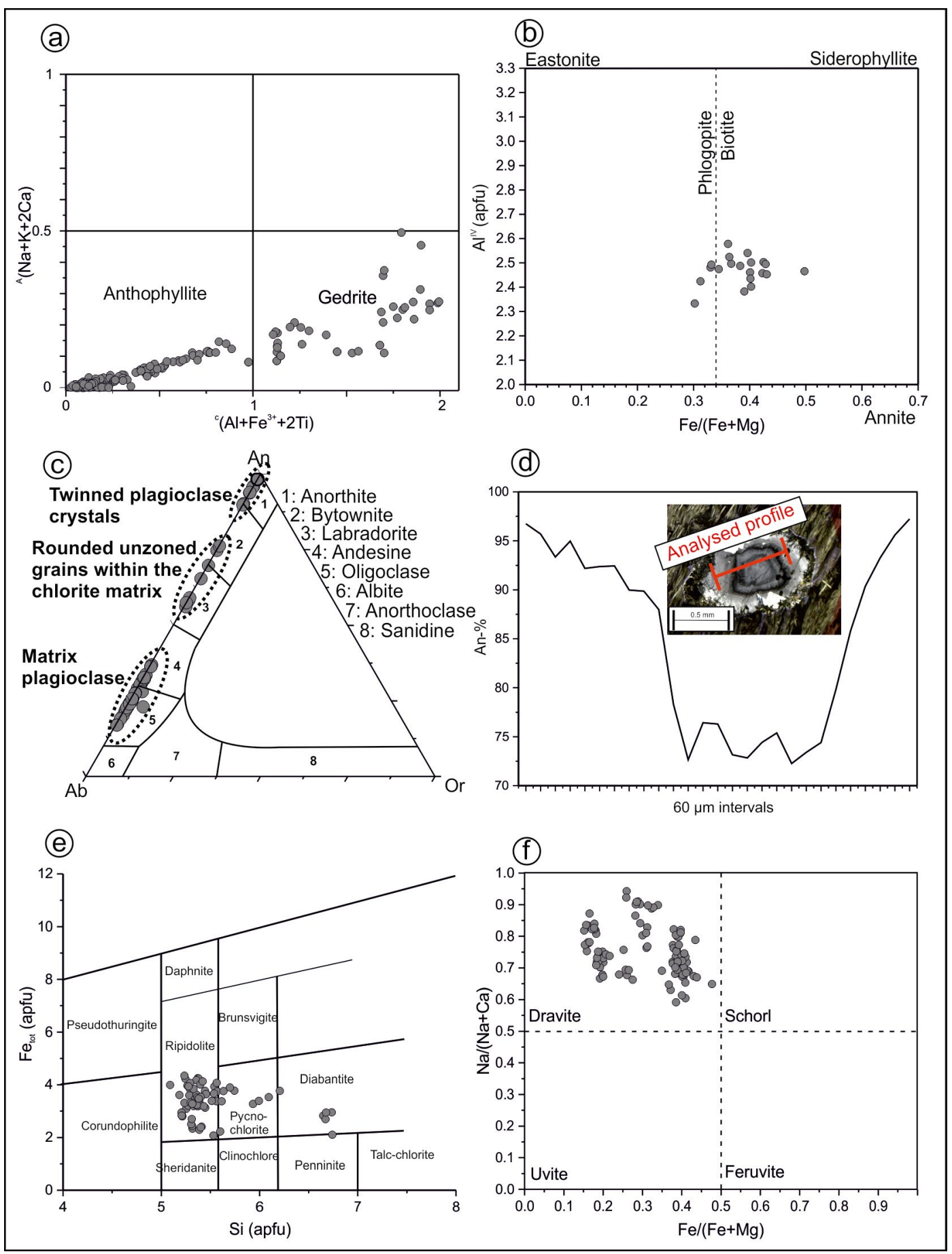

Figure 10. Mineral compositional data from cordierite-orthoamphibole rocks at Palokas. a) Binary amphibole classification diagram after Hawthorne et al. (2012). b) Biotite classification diagram after Deer (1992). c) Ternary diagram for feldspars. d) Compositional cross-section of a plagioclase grain showing oscillatory reverse zoning. Inset shows a photomicrograph of the grain and the analytical transect (red line). e) Chlorite classification diagram after Hey (1954). f) Tourmaline classification diagram. 
Figure 11. Chondrite-normalized REE patterns for tourmaline from the Palokas gold occurrence and tourmaline from the tourmaline granite in the vicinity. A whole-rock analysis of the tourmaline granite (after Ranta et al., 2015b) is given for comparison. Normalization values are after Boynton (1984).

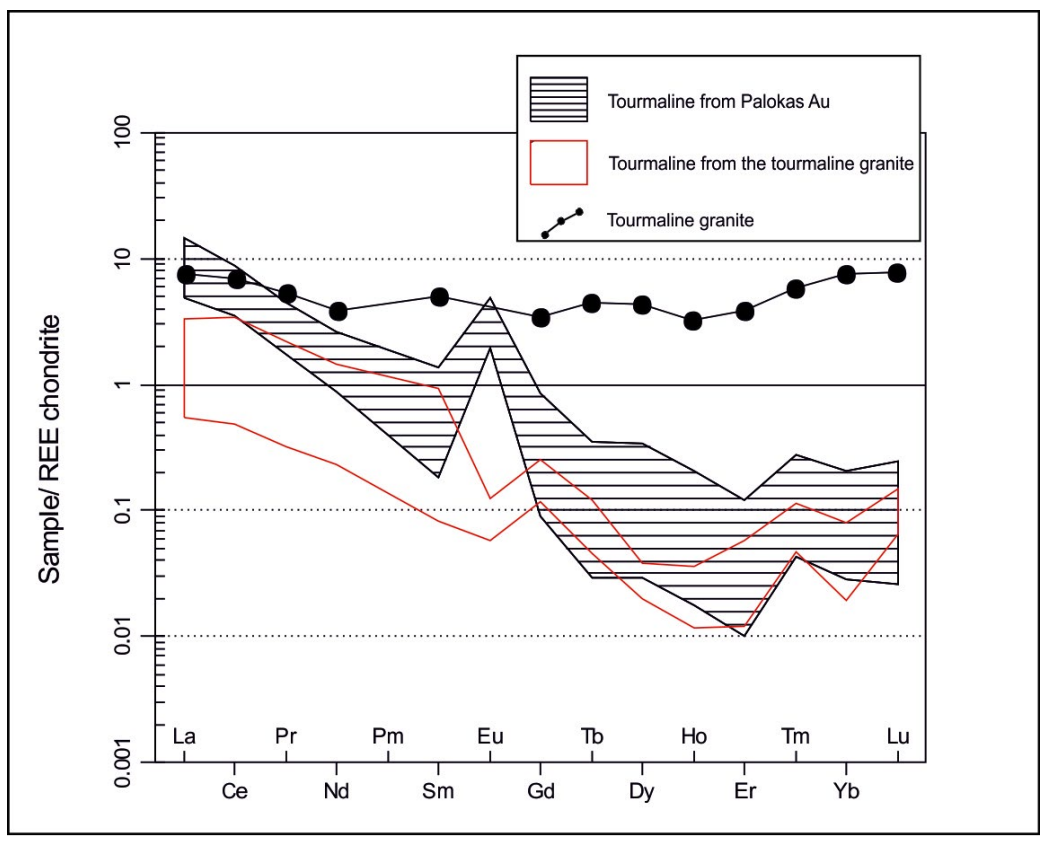

(e.g., Henry \& Dutrow, 1996). Secondary fluid inclusions are relatively small and have two-phase composition at room temperature. Following the guidelines of Roedder (1984), isolated fluid inclusions, or those occurring in $3 \mathrm{D}$ clusters with no clear relation to fractures, were classified as primary. They can be divided into two fluid inclusion types according to their phase composition observed at $40{ }^{\circ} \mathrm{C}$ and considering their microthermometric and Raman spectrum data. Type 1 inclusions have aqueous liquid + carbonic vapor ( $\mathrm{Laq}+\mathrm{Vcar})$ composition with a highly variable degree of filling (DF; vapor/total inclusion volume) ranging approximately from 0.3 to 0.7 . Type 2 fluid inclusions have aqueous liquid+carbonic liquid (Laq+Lcar) phase composition and their DF is also highly variable between $0.3-0.8$. Most of Type 2 inclusions show $\mathrm{Laq}+\mathrm{Lcar}+\mathrm{V}$ car phase composition at room temperature. Figure 12 illustrates the common primary fluid inclusion types found in tourmaline grains. The primary fluid inclusions are mostly found as isolated inclusions with variable DF, but when occurring in groups, they usually show relatively constant DF around 0.4 . However, in some assemblages of Type 2 inclusions, highly variable DF ratios were also detected. Type 1 and
Type 2 have not been observed to occur together in recognizable fluid inclusion assemblages (FIA). No clear relationships between the occurrence of types of primary fluid inclusions and rims or cores of the tourmaline crystals have been observed.

\subsubsection{Results of fluid inclusion microthermometry}

Microthermometric results for the measured individual fluid inclusions are given in Electronic Appendix C. Many Type 2 inclusions decrepitated upon heating before attaining total homogenization. Therefore, homogenization runs were performed after observations on the freezing behavior of inclusions.

Type 1 fluid inclusions showed freezing temperatures of carbonic phase from -75 to $-100{ }^{\circ} \mathrm{C}$ (avg. $-96^{\circ} \mathrm{C}$ ). Carbonic phase melting temperatures $\left(\mathrm{Tm}_{\mathrm{car}}\right)$ range between -61.6 and $-57.7^{\circ} \mathrm{C}$ (avg. $-59.3{ }^{\circ} \mathrm{C}$ ), well below the $\mathrm{CO}_{2}$ triple point temperature $\left(-56.6{ }^{\circ} \mathrm{C}\right)$, indicating the presence of additional volatile species in the carbonic phase. The clathrate melting temperatures $\left(\mathrm{Tm}_{\text {clath }}\right)$ are between 5 and $10{ }^{\circ} \mathrm{C}$, with an average value at $8{ }^{\circ} \mathrm{C}$. Partial homogenization temperatures 

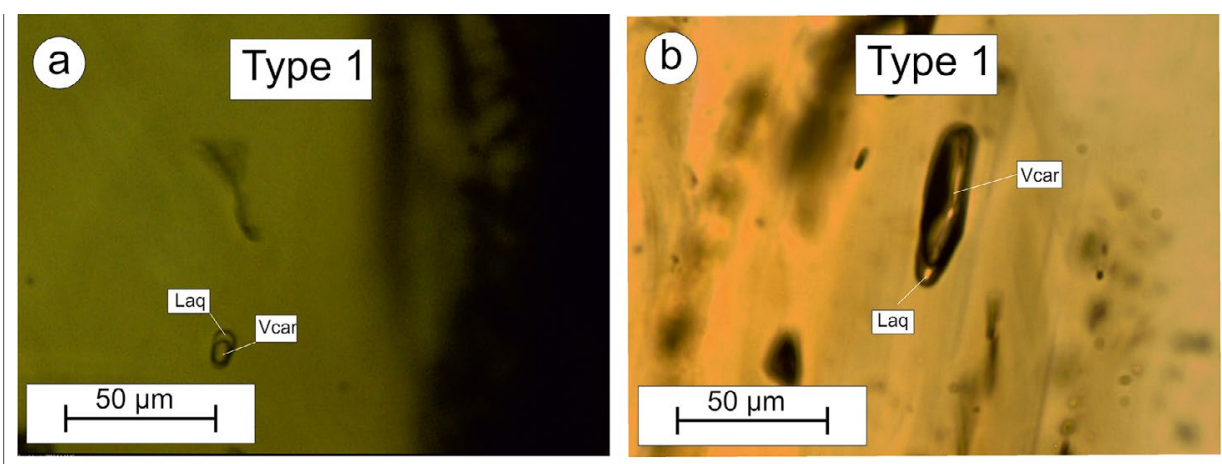

Figure 12.

Photomicrographs of primary fluid inclusions found in tourmaline grains. In a-c, Type 1 fluid inclusions with variable DF-ratios. In $\mathrm{d}-\mathrm{e}$, isolated Type 2 fluid inclusions with a double bubble at room temperature. f) Type 2 fluid inclusions.
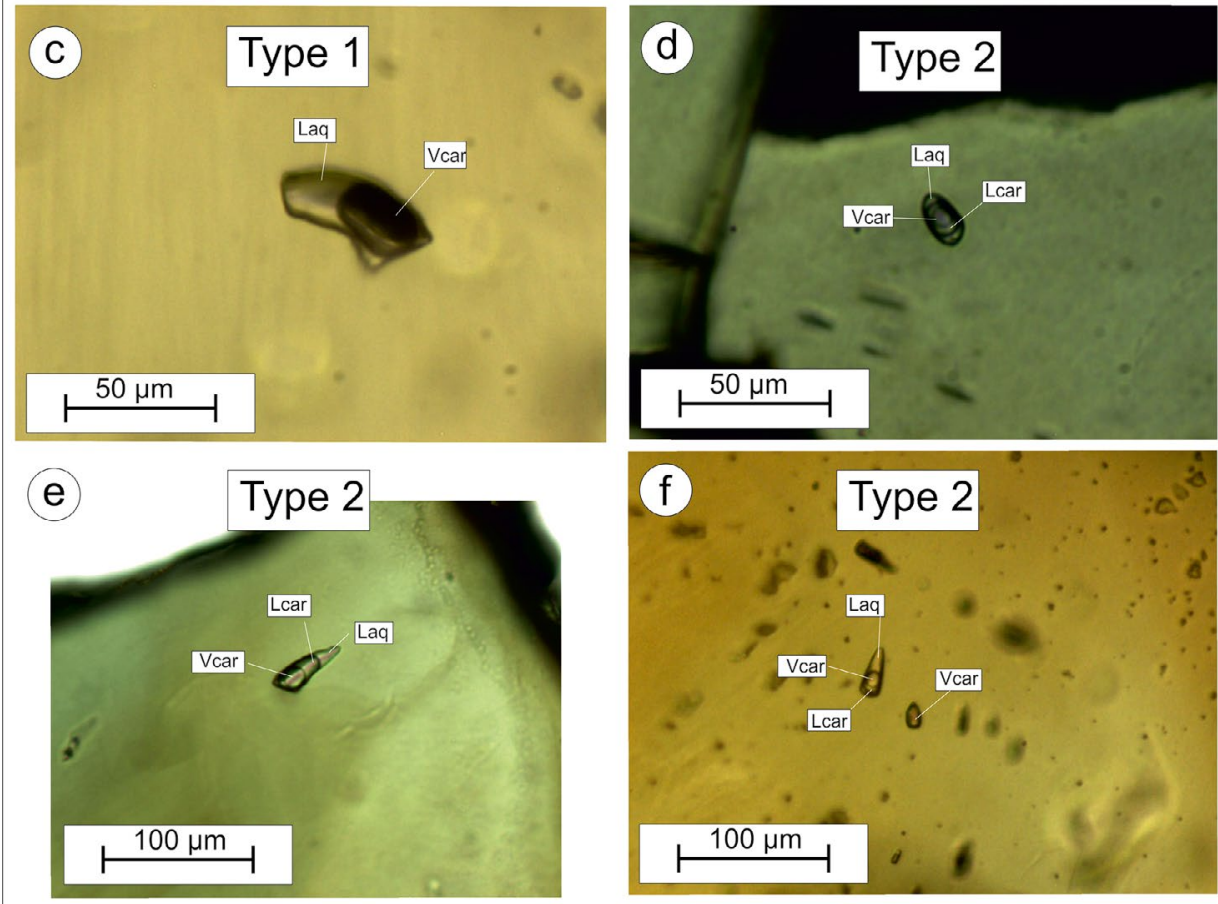

of carbonic phases (Th car) are between 15 and 27 ${ }^{\circ} \mathrm{C}$; homogenization of carbonic phases took place into a vapor phase. Type 1 fluid inclusions with DF between $0.3-0.4$ showed total homogenization into an aqueous liquid phase, whereas this type of inclusions with DF between 0.6 and 0.7 homogenized into carbonic vapor phases. These contrasting modes of total homogenization took place between 280 and $405^{\circ} \mathrm{C}$ (Fig. 13).

Type 2 fluid inclusions showed freezing temperatures of carbonic phase from -90 to $-105^{\circ} \mathrm{C}$ (avg. $\sim 99^{\circ} \mathrm{C}$ ). Carbonic phase melting temperatures range between $-60.1{ }^{\circ} \mathrm{C}$ and $-57.6^{\circ} \mathrm{C}\left(\right.$ avg. $\left.-58.6^{\circ} \mathrm{C}\right)$, indicating additional volatile species in the carbonic phase, as was the case with the Type 1 fluid inclusions. The clathrate melting temperatures are between 6.1 to $9.9{ }^{\circ} \mathrm{C}$, with an average value of $8.6{ }^{\circ} \mathrm{C}$. Partial homogenization temperatures of the carbonic phase $\left(\mathrm{Th}_{\mathrm{Car}}\right)$ into carbonic liquid are between 22.5 and $27.7^{\circ} \mathrm{C}$. Type 2 fluid inclusions showed a range of total homogenization temperatures $\left(\mathrm{Th}_{\mathrm{too}}\right)$ into the carbonic liquid phase and some of them featured "critical" homogenization (e.g., fading of the meniscus between the aqueous liquid and carbonic liquid without a significant change in the volume of the carbonic phase) between 272 and $375{ }^{\circ} \mathrm{C}$ (Fig. 13). Type 2 inclusions with relatively low DF (0.3-0.4) 
Figure 13. Histogram of homogenization temperatures for primary Type 1 and Type 2 fluid inclusions in tourmaline.

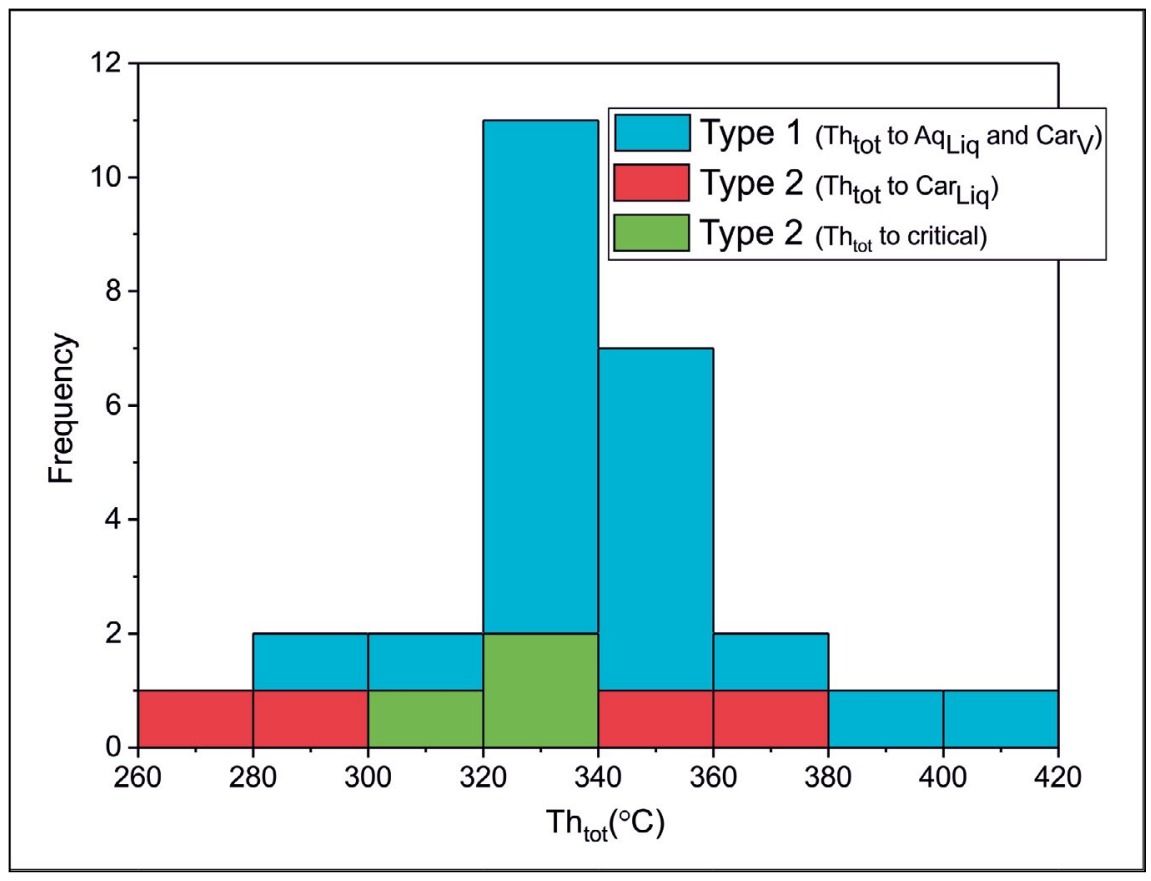

showed the critical homogenization, whereas Type 2 inclusions with relatively high DF (0.7-0.8) showed total homogenization into carbonic liquid.

\subsubsection{Results of Raman spectroscopy}

Raman spectroscopy results for the measured individual fluid inclusions are given in the ESM Table 2. The total homogenization temperature observations from the Type 1 fluid inclusions, which homogenized into a vapor phase, are challenging due to the optical properties of the host mineral. An attempt was made to re-check the temperatures by continuous monitoring of the Raman spectrum during heating (e.g., Gál et al., 2013). However, this was unsuccessful due to the strong $\mathrm{OH}$-group spectra from host tourmaline, which masked the spectrum of the water in the fluid inclusions.

Raman spectroscopy measurements of the homogeneous carbonic phases in Type 1 inclusions were performed at room temperature. In order to obtain the composition of a homogeneous carbonic liquid phase, Type 2 fluid inclusions were heated up to $32^{\circ} \mathrm{C}$, i.e., above the critical temperature of $\mathrm{CO}_{2}$ $\left(31.1^{\circ} \mathrm{C}\right)$. Attempts were also made to measure the bulk composition by heating fluid inclusions above their total homogenization temperatures. However, the broad $\mathrm{H}_{2} \mathrm{O}$ Raman band was completely overprinted by structurally bounded $\mathrm{H}_{2} \mathrm{O}$ in the host tourmaline and thus the bulk composition based on Raman spectra could not be determined.

Both in the Type 1 and Type 2 fluid inclusions, the presence of $\mathrm{CH}_{4}$, in addition to $\mathrm{CO}_{2}$, was observed in the Raman spectra. In the Type 1 fluid inclusions, homogenizing into an aqueous liquid phase, the estimated amount of $\mathrm{CH}_{4}$ in the carbonic phase varies between 2.8 and 7.1 mol.\% (avg. 4.73 mol.\%; $\mathrm{n}=3$ ). In the Type 2 inclusions, the estimated $\mathrm{CH}_{4}$ content in the carbonic phase is between 2.2 and $14.5 \mathrm{~mol}$ \% (avg. $5.2 \mathrm{~mol} . \%$; $\mathrm{n}=13$ ). The presence of traces of $\mathrm{H}_{2} \mathrm{~S}$ was only observed in one of the Type 2 inclusions.

\subsubsection{Salinities of fluid inclusions}

Salinities were calculated based on the $\mathrm{CO}_{2}$ clathrate melting temperatures. All the fluid inclusions showed clathrate melting temperatures 
below the partial homogenization temperature of the carbonic phase, and the equilibrium phases during the clathrate melting were Laq+Lcar+Vcar and clathrate (see Diamond, 2001). This indicates Q2-type melting paths, and the salinites were calculated accordingly. The salinities in the Type 1 fluid inclusions vary between 0.2 and 8.9 wt. $\%$ equiv. $\mathrm{NaCl}$ (avg. 6; $\mathrm{n}=9$ ), whereas in the Type 2 fluid inclusions, they range from 1.6 to $6.9 \mathrm{wt} . \%$ equiv. $\mathrm{NaCl}$ (avg. 3.7; $\mathrm{n}=6$ ).

\section{Discussion}

\subsection{Hydrothermal environment and precipitation of gold}

Hydrothermal alteration associated with the Palokas gold mineralization is locally very intense. Reduced sulfur and Fe-Mg-B-S metasomatism is most notably manifested by abundant chlorite, tourmaline, pyrrhotite, magnetite, and the local presence of $\mathrm{H}_{2} \mathrm{~S}$ (in one Type 2 fluid inclusion of tourmaline). Alteration mostly took place along the late quartz veins and it extended up to several meters outwards into the host rock. Sulfide dissemination is also found outside of the chloritic core intervals and, based on the drillcore observations together with gold assays, gold locally follows the distribution of sulfides (data from Mawson Resources Ltd., see Fig. 3). Petrographic and structural observations (Mawson Resources Ltd. internal report, Nick Oliver, pers. comm., 2017) suggest that pyrrhotite most probably occurs in multiple generations, as indicated by the appearance of multi-deformed pyrrhotite bands following the foliation and the presence of late brecciated sulfide networks. However, identifying the number of generations and their relationship to each other requires detailed structural mapping on a much larger scale, which is beyond the scope of this study. The occurrence of gold in two textural settings allows us to hypothesize multiple goldprecipitating events, with earlier coarser-grained gold occurring within silicates in the host rocks and the later events forming the brecciated veins and gold in fractures.

\subsection{Composition, density, and trapping temperature-pressure estimates of fluid inclusions}

Fluid inclusions with contrasting phase composition and homogenization behavior are usually observed as single inclusions in tourmaline occurring in the gold mineralization at Palokas. Rarely, when they occur in groups, no mingling with the different types of fluid inclusions is observed. If the Type 1 fluid inclusions are synchronously trapped, the variability in Type 1 suggests heterogeneous fluid system during the entrapment. The Type 2 fluid inclusions, like those of the Type 1, are usually found as single isolated inclusions. They show total homogenization to the carbonic liquid and, based on critical homogenization and microthermometric behavior, may also be interpreted as entrapment of fluid inclusions from a heterogeneous fluid system. Volume fractions of vapor and liquid phases have an effect on the bulk composition of fluid inclusions and their density calculations. Because of the unsuccessful attempts to determine the bulk composition by Raman analyses on the total homogenization temperatures, the calculated bulk densities and bulk composition are based on visual DF estimates of the liquid and vapor phases. Because of the three dimensional form of the fluid inclusions, microscopic visual estimates of DF ratios are essentially $2 \mathrm{D}$ views and thus can be highly biased. In spite of this, the highly variable phase compositions and DF observed in Type 1 and Type 2 inclusions together with their microthermometric behavior point to a heterogeneous (boiling) fluid state at the time of their entrapment.

Bulk composition estimates for the Type 1 model inclusions (DF based on visual estimates) are listed in Table 4. For the Type 1 fluid inclusions, a bimodal distribution in terms of the calculated bulk densities is clearly observable. Owing to 
the relatively low number of successful Raman analyses from those fluid inclusions, which also have complete microthermometric measurements, model fluid inclusions with representative properties were chosen. Using these properties, calculations were completed with various DF values in order to demonstrate the combined effect of the error in the visual estimates and the potential occurrence of inhomogeneous entrapment of mixtures of vapor and liquid phases from a heterogeneous parent fluid system. Fluid inclusions that were homogenized into an aqueous liquid phase (DF $=0.3-0.4$ ) at around $300{ }^{\circ} \mathrm{C}$ have bulk densities from -0.74 to $0.66 \mathrm{~g} / \mathrm{cc}$. Calculated pressures at $300{ }^{\circ} \mathrm{C}$ are between 377 and 280 bar. No Raman data are available for the Type 1 fluid inclusions homogenized into a carbonic vapor phase. Based solely on the microthermometry and assuming a pure $\mathrm{CO}_{2}-\mathrm{CH}_{4}$ composition for the carbonic phase, molar fractions of $\mathrm{CO}_{2}$ and $\mathrm{CH}_{4}$ were estimated using vX diagrams of Thiéry et al. (1994). Accordingly, the mole fraction of $\mathrm{CH}_{4}$ $\left(\mathrm{XCH}_{4}\right)$ in the carbonic phase of these inclusions is 0.12 and the calculated bulk densities are between 0.5 and $0.42 \mathrm{~g} / \mathrm{cc}$ for DF estimates from 0.6 to 0.7 . The calculated pressures at $300{ }^{\circ} \mathrm{C}$ are between 230 and 162 bars. This pressure range is similar to the calculated pressures in the Type 1 inclusions at the temperature of total homogenization into a carbonic vapor phase. This result indicates that all the Type 1 inclusions were probably trapped from the same heterogeneous carbonic-aqueous fluid.

The calculated total densities for the Type 2 fluid inclusions with total homogenization into a carbonic liquid phase vary from 0.75 to $0.71 \mathrm{~g} / \mathrm{cc}$, with volume fraction estimates between 0.7 and 0.8 . The calculated pressures at $300{ }^{\circ} \mathrm{C}$ range from 1271 (DF 0.7) to 1136 bars (DF 0.8). Those Type 2 fluid inclusions that were homogenized into a critical mode have calculated densities between 0.88 and $0.85 \mathrm{~g} / \mathrm{cc}$, with DF between 0.3 and 0.4 . The calculated pressures at $300{ }^{\circ} \mathrm{C}$ are between 2250 (DF 0.3) and 1927 bars (DF 0.4). Bulk composition estimates for the Type 2 model inclusions (DF based on visual estimates) are shown in Table 4. These data suggest that the Type 2 inclusions were also trapped from a heterogeneous aqueous-carbonic fluid under the conditions close to the critical temperature-pressure of the fluid phase (e.g., $325^{\circ} \mathrm{C}$ and $1.5 \mathrm{kbar}$ ).

Assuming an average density for metamorphic rocks $\left(3000 \mathrm{~kg} / \mathrm{m}^{3}\right)$, the estimated formation depth for the Type 2 fluid inclusions is around $5 \mathrm{~km}$ based on the calculatedpressure of $1.5 \mathrm{kbar}$. Under hydrostatic conditions with around 0.5 to max. 1 bulk density of carbonic-aqueous fluids, the $5 \mathrm{~km}$ depth corresponds to pressures of 250-500 bars, which is a range that is also characteristic to the entrapment conditions of the Type 1 inclusions. Thus, it is plausible that the primary fluid inclusions in tourmaline were trapped from a boiling aqueouscarbonic fluid system, with the pressure waving between lithostatic and hydrostatic values at a depth of around $5 \mathrm{~km}$. Even though we cannot make straightforward conclusions about gold precipitation based on the fluid inclusions found in the tourmaline, as gold is located in fractures in the tourmaline, boiling of hydrothermal fluids is a powerful mechanism to precipitate gold (e.g., Drummond \& Ohmoto, 1985). The brecciated nature of sulfides and the mode of occurrence of gold in late tourmaline-rich veins is also consistent with this model.

\subsection{Genetic classification of the Rompas-Rajapalot Au occurrences}

In order to establish a genetic model for the Palokas gold occurrence, one must take into consideration the features found within the whole mineralized system and their relationship to the geological evolution of northern Finland. From $1.93 \mathrm{Ga}$ to $1.83 \mathrm{Ga}$, the bedrocks in northern Finland experienced three major collisional events (Lapland-Kola orogen, Norbotten-Karelia orogen and Svecofennian orogen), followed by thrusting, crustal thickening, metamorphism, and, finally, orogenic collapse of the formed mountain 


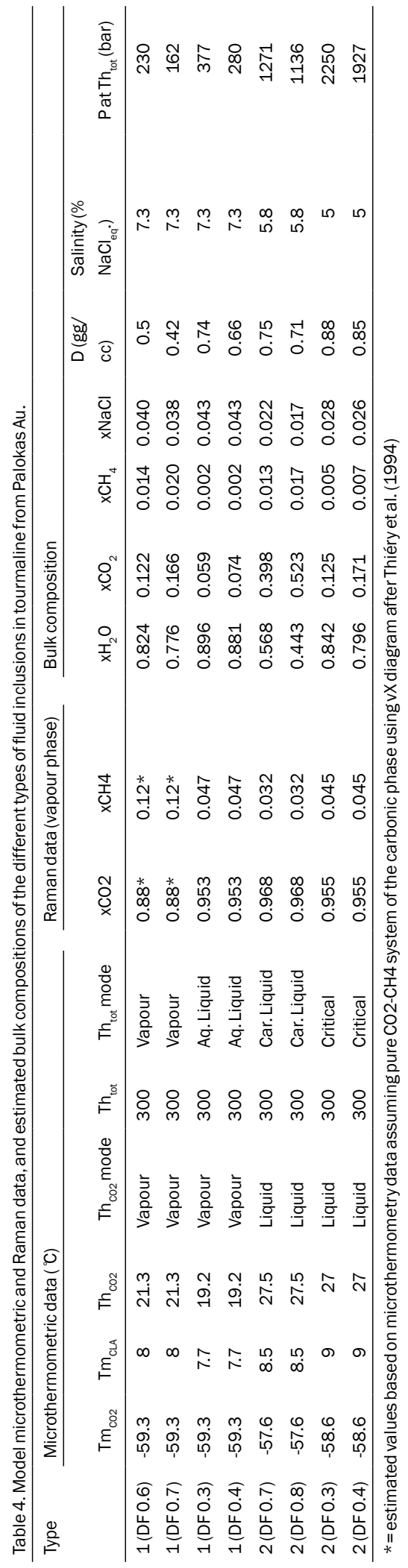

ranges (Nironen, 2017, and references therein). In addition, formation of major shear zones at this time played an important role in later re-activation of these shear zones and movements of metal-rich hydrothermal fluids during the later stages of the Svecofennian orogeny $(1.84-1.77 \mathrm{Ga})$ and related formation of orogenic gold deposits in Finland (Molnár et al., 2017b).

Paleoproterozoic granites in Finland are divided into pre- $(1.95-1.91 \mathrm{Ga})$, syn- $(1.89-1.86 \mathrm{Ga})$, late$(1.84-1.80 \mathrm{Ga})$ and post-orogenic $(1.80-1.77 \mathrm{Ga})$ types (Nironen, 2005). In the Peräpohja belt, the pre-orogenic granitoid group is represented by the 1.99 Ga Kierovaara granite (Ranta et al., 2015b), while the ca. 1.88 Ga Haaparanta Series plutonic rocks cutting the youngest sedimentary formation in the Peräpohja belt belong to the synorogenic granitoid group. In terms of the age, the post-orogenic granitoids are represented by the granitoids dated between 1.79-1.77 Ga in the northern part of the Peräpohja belt, including the tourmaline-rich pegmatitic granite in the vicinity of the Palokas gold mineralization. However, even though the granitoids are similar in age to those of the post-orogenic granitoid group, in other locations they cannot be classified as postorogenic, as many of them commonly show foliation and were, thus, emplaced during or before tectonic activity (e.g., Ahtonen et al., 2007; Lauri et al.,2012; Ranta et al., 2015b). According to Ahtonen et al. (2007), at 1.79-1.76 Ga, the northern Fennoscandian Shield was affected by intensive deformation, metamorphism, and melting, which were coeval with the post-orogenic magmatism in the southern part of the Shield. It is clear from our work in the area that the granites were emplaced at the very end of this tectonic cycle. This interpretation is based on field relationships, lack of internal fabric development and local porphyritic textures, which indicate post-tectonic emplacement across the boundary of the main Central Lapland Granitoid belt.

Many lines of evidence, including the late appearance of gold in the fractures, the occurrence of granitoids within the mineralized 
area, the $1.78 \mathrm{Ga}$ age for the molybdenite related to gold (Molnár et al., 2017a), and the boron isotope composition of tourmaline, bring us to the conclusion that the fracture-related gold mineralization event was coeval with the $1.78 \mathrm{Ga}$ granitoid magmatism (Ranta et al., 2017). Molnár et al. (2016) also proposed the same relationship with regard to the timing of the gold deposition in the Rompas deposit. Gold seems to occur at least in two textural settings at Palokas, as in addition to fracture-related gold, native grains are found within silicates with no clear relationship to any fractures. The timing of formation of this type of gold mineralization is still not clear. There are some shared similarities with the Palokas occurrence and some genetic types of gold deposits. In the following, we compare the features displayed by the Palokas occurrence with those reported from different genetic types of gold deposits. The focus is on the two main genetic types found in metamorphosed supracrustal belts globally, i.e., the orogenic and reduced intrusion-related gold deposits (Goldfarb et al., 2005). Many of the features observed are not specific to a single genetic type, which makes the classification difficult. Moreover, many crucial features typical of the two genetic types mentioned above are lacking or not yet discovered in the Rompas-Rajapalot occurences.

Goldfarb et al. (2001) suggested that in the areas where Paleoproterozoic tectonic activity resulted in deformations within older intracratonic basins, orogenic gold deposits could show anomalous metal associations, most notably $\mathrm{Ag}, \mathrm{Cu}$, $\mathrm{Co}, \mathrm{Ni}$ or $\mathrm{Sb}$, due to the saline ore fluids released from evaporitic strata during metamorphism (e.g., Yardley \& Cleverley, 2013). It is clear that such fluid circulation has been active in the Karelian supracrustal cover sequences, which resulted in widespread albitization of the rocks (e.g., Eilu, 1994; Vanhanen, 2001; Melezhik et al., 2012). This laid the groundwork for later ore-forming processes by producing competent host lithologies.

In general, orogenic gold deposits, a class defined by Groves et al. (1998), form at a wide range of depths between 2 and $20 \mathrm{~km}$, most commonly during compressional to transpressional deformation in accretionary or collisional forearc or back-arc settings. The metamorphic grade is generally greenschist facies, although significant ore bodies are also found in higher-grade rocks (e.g., Goldfarb and Groves, 2015). The host rocks for orogenic deposits can be any supracrustal rocks or intrusions within metamorphic belts. The mineralization style is dependent on the P-T conditions (e.g., the crustal continuum model by Groves, 1993) varying from ductile environments $\left(\geq 400{ }^{\circ} \mathrm{C}\right.$ and 2.5 kbars) with disseminated $\mathrm{Au}$ lodes in broad shear zones with bedding parallel to deformed and recrystallized quartz veins to brittle stockworks and breccias. The timing of the gold precipitation is commonly late metamorphic (e.g., Goldfarb et al., 2005). Gold is hosted in quartz veins or in host rocks adjacent to veins. Alteration halos include As, Au, Bi, K, Rb, Sb, Te and W. Most of the gold is in a native form, located in fractures of sulfides or between sulfide grains. Locally, gold is closely associated with $\mathrm{Bi}-$, Sb- and $\mathrm{Te}-$ bearing minerals (e.g., Goldfarb et al., 2005). Eilu (2015) pointed out that the late to postorogenic shearing and brittle fracturing may result in local remobilization of earlier-formed gold into fractures.

Sillitoe (1991) proposed an intrusion-related genesis for a broad range of gold mineralization styles in the Circum-Pacific arc settings, though a common connection between gold deposition and granites has been recognized over many centuries (Hart \& Goldfarb, 2005, and references therein). The intrusion-related gold system model (IRGS) was introduced by Lang et al. (2000). It was modified by Thompson \& Newberry (2000) to the reduced IRGS model in order to emphasize the reduced state of the associated granites. Essentially, the reduced IRGS model is based on the presence of a cooling magmatic body producing a localscale fluid convection. Hart \& Goldfarb (2005) summarized the key features of the reduced IRGS. These features are observed in the Tintina Gold Province in Alaska, which serves as a reference locality for the reduced intrusion-related gold deposit model proposed by these authors. Many 
of these features are similar to those in other hydrothermal deposit types (e.g., orogenic gold deposits), including a Bi-Te-W association, reduced sulfide assemblages and a spatial association of the gold mineralization with granites. However, some of the key features can be different, for example, from the characteristics of orogenic gold deposits. One of them is the timing of the mineralization event. The reduced IRGS involves almost solely post-orogenic ore formation, subsequently to regional metamorphism and deformation (Hart \& Goldfarb, 2005, and references therein). This is in contrast to orogenic gold deposits, in which the timing of the gold mineralization is syn- to late orogenic, with fluids most likely being derived from metamorphic devolatilization (e.g., Groves et al., 1998). Reduced intrusion-related gold systems can form at various depths, ranging from $<1$ to $>8 \mathrm{~km}$, usually between 4 and $6 \mathrm{~km}$ (Hart \& Goldfarb, 2005). Based on fluid inclusion studies and types of mineral assemblages, the estimated formation pressures vary significantly, between 0.3 to $3.5 \mathrm{kbar}$ (e.g., Baker \& Lang, 2001). Fluids are rich in $\mathrm{H}_{2} 0$ and $\mathrm{CO}_{2}$, with the salinities ranging from $>30 \mathrm{wt} . \%$ $\mathrm{NaCl}$ (shallow environment) to $<5$ wt. $\% \mathrm{NaCl}$ (deep environment) (Baker, 2002). According to Baker (2002), variable fluid types are related to a complex exsolution of different volatiles from felsic magmas at different crustal levels.

The association of $\mathrm{Te}-\mathrm{Cu}-\mathrm{Co}-\mathrm{Se}-\mathrm{Bi}-\mathrm{Mo}-\mathrm{W}-\mathrm{Ag}$ $\mathrm{Au}$ at Palokas and the close spatial relationship of $\mathrm{U}$ and gold mineralization in the entire RompasRajapalot area are not typical of either the orogenic gold system or the reduced intrusion-related gold deposit system. However, as we are dealing with old metamorphosed intracratonic basins, it is probable that several hydrothermal events have occurred there, each of them was accompanied by metal precipitation. Molnár et al. (2016) proposed that the uranium enrichment took place prior to that of gold at Rompas, initially during pre-orogenic processes and subsequently during re-mobilization related to metamorphism. Moreover, the structural control, which is the most important feature in orogenic gold, is not yet identified in the Rompas-
Rajapalot system, but reactive rock types and chemical traps seem to be more important for the precipitation process in the area (e.g., Molnár et al., 2016).

According to Goldfarb et al. (2005), the following features of the reduced intrusion-related gold systems are distinguishable in the orogenic gold deposits; these can be used as criteria when evaluating the genetic model of a deposit:

1) Low Au grade (<1 g/t in RIRGS vs. 5-10 g/t in orogenic gold deposits). Based on the current estimates for the mineralization grades at the Rompas-Rajapalot area, this does not seem to be the case. However, these occurrences are still at the exploration stage and no resource estimations have been done yet.

2) Location in a deformed shelf sequence inland from accreted terranes. The regional geological framework of the Peräpohja belt (intracratonic rift basin) fits this requirement.

3) Regional association with tungsten andlor less consistently, tin lodes. Elevated W in the goldcritical areas is a typical feature of the Palokas Au occurrence; this is evident from the correlation between $\mathrm{W}$ and Au in the geochemical data (see Table 3). Scheelite is a common mineral in the area and a spatial correlation with scheelite and gold can be seen in drill core. However, so far, no tin lodes have been found.

4) A post-deformational timing relative to a late synorogenic timing for orogenic gold deposits. The Re-Os isotope data on molybdenite associated with gold in the tourmaline-rich zones at Palokas yield an age of $1.78 \pm 0.01 \mathrm{Ga}$ (Molnár et al., 2017a). This is consistent with the age of a pegmatitic tourmaline-rich granite in the vicinity of the Palokas occurrence. The granite seems to show no deformation and thus could be classified as post-deformational. However, as stated above, at 1.79-1.76 Ga, the northern Fennoscandian Shield was affected by intensive deformation, metamorphism, and melting and, hence, classification of granitoids of that age as post-deformational is misleading.

5) Anomalous granitoid system reflecting some input 
from mantle-derived mafic alkaline magmas into the base of the crust. In general, the 1.79$1.77 \mathrm{Ga}$ granitoids in the Peräpohja belt and in the Central Lapland show negative initial $\varepsilon_{\mathrm{Nd}}$ values indicating a strong crustal component from the underlying Archean basement (e.g., Ahtonen et al., 2007; Ranta et al., 2015b). Appinitic rocks of post-collisional ages (1796 \pm 4 Ma; Väänänen, 2004) have been reported from the Central Lapland Granitoid belt and from the Peräpohja belt, indicating the presence of mantle-derived magmatism. Based on the features observed so far from the Palokas occurrence, the classification of the Rompas-Rajapalot $\mathrm{Au}$ occurrences as an example of the reduced intrusionrelated gold system does not appear to be appropriate. The specific metal association and reduced sulfide assemblage, the spatial and temporal relationship with granitoids and the involvement of low- to moderate salinity $\mathrm{H}_{2} \mathrm{O}-\mathrm{Na}_{2} \mathrm{O}-\mathrm{CO}_{2}-\mathrm{CH}_{4}-\left(\mathrm{H}_{2} \mathrm{~S}\right) \quad$ hydrothermal fluids are not diagnostic features for any single deposit type, but can be related, for example, to orogenic gold deposits (Goldfarb et al., 2005). Furthermore, the most distinguishing feature for the reduced intrusion-related gold system, the presence of sheeted auriferous veins within the granites, seem to be missing. Geophysical (gravity and aeromagnetic) data of Mawson Resources Ltd. obtained from the granite outcrops suggest the existence of subsurface granitic rocks in the Rompas-Rajapalot area (see Fig. 2) and, thus, there remains a possibility of the presence of such sheeted veins.

\subsection{Origin of the cordierite- orthoamphibole rocks and calcsilicate-albite rocks}

Since the early $20^{\text {th }}$ century, cordierite-orthoamphibole rocks in metamorphic terrains have attracted attention of petrologists and economic geologists owing to their unusual bulk composition and common association with massive sulfide deposits (e.g., Eskola, 1914; Reinhardt, 1987; Pan \& Fleet, 1995). Generally, cordierite-orthoamphibole rocks have been interpreted to form through pre- to synmetamorphic metasomatic alteration of various rock types ranging from granitic rocks to felsic and mafic volcanic rocks (e.g., Schumacher, 1988; Pan \& Fleet, 1995; Roberts et al., 2003; Peck \& Smith, 2005; Pitra et al., 2008). A widely accepted interpretation of the formation of cordieriteorthoamphibole rocks is pre-metamorphic hydrothermal alteration in a sub-seafloor system followed by amphibolite-facies regional metamorphism (e.g., Pan \& Fleet, 1995). In addition, isochemical metamorphism of $\mathrm{Mg}$ - rich sedimentary rocks, such as evaporites or clastic sediments derived from ultramafic rocks, have been suggested (Moine et al., 1981; Reinhardt, 1987).

To evaluate potential rock types as protoliths for the Palokas cordierite-orthoamphibole rocks, their major- and trace-element compositions are compared with chemical data of volcanic and sedimentary rocks from the Peräpohja belt, as well as literature data on cordierite-orthoamphibole rocks. In Fig. 14, trace element data of the Palokas cordierite-orthoamphibole rocks, calcsilicate rocks and amphibolites are plotted together with those of mafic volcanic rocks from the Peräpohja belt, as represented by the Jouttiaapa and Runkaus Formations. The cordierite-orthoamphibole and calcsilicate rocks are clearly distinct from the mafic volcanic rocks, whereas the amphibolites from the Palokas area plot within the field of the Runkaus Formation.

In Fig. 15, the Palokas cordierite-orthoamphibole rocks are compared with the Petäjäskoski Formation (Kyläkoski et al., 2012) and cordieriteorthoamphibole rocks from the literature, mostly those studied by Reinhardt (1987). In terms of the trace element systematics, the Palokas cordieriteorthoamphibole rocks are generally similar to the Petäjäskoski Formation and the cordieriteorthoamphibole rocks from the Reinhardt (1987) study. Also, their trace element compositions match well the typical compositional range of shales and 


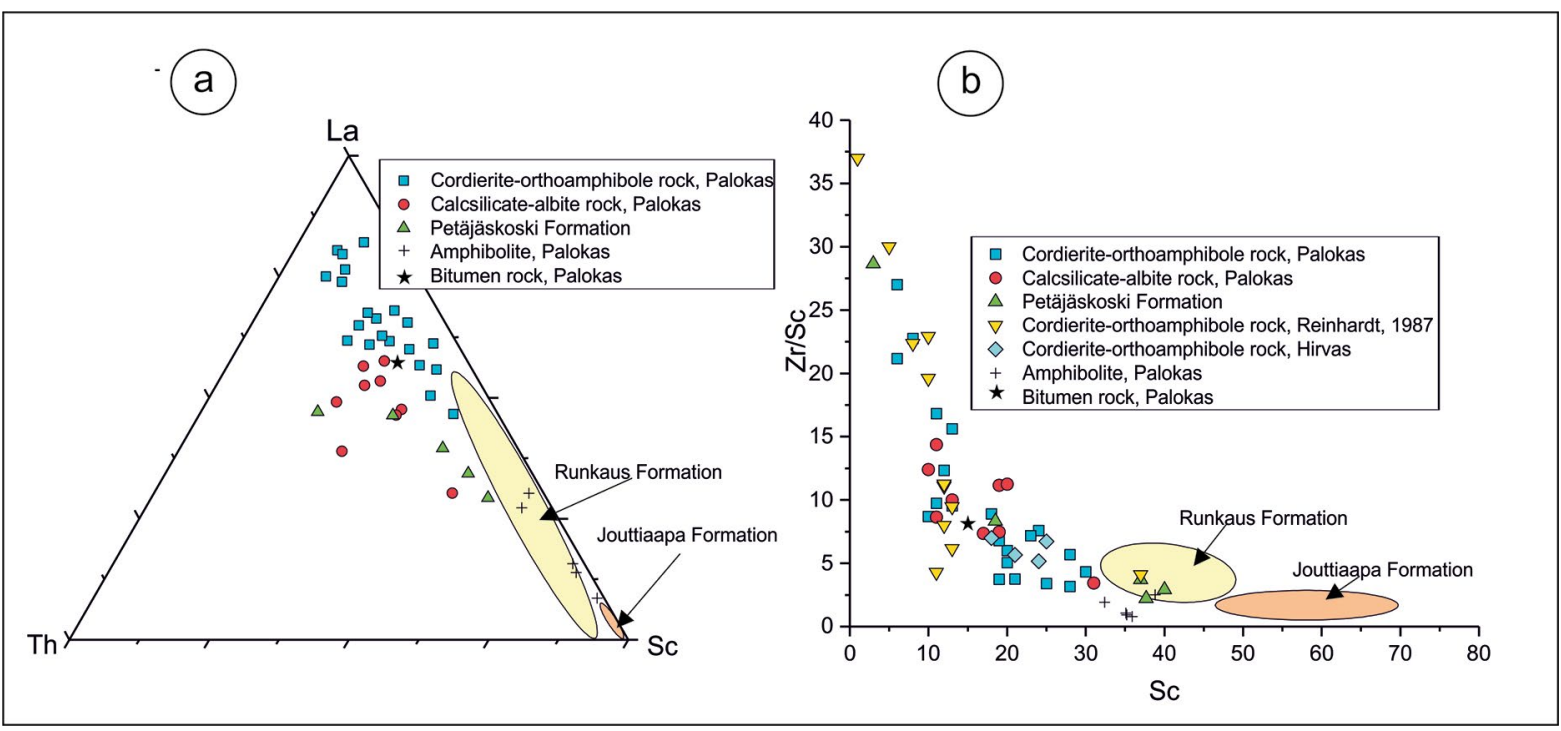

Figure 14. Trace element contents of cordierite-orthoamphibole rocks at Palokas compared with those from the Petäjäskoski Formation (Kyläkoski et al., 2012), cordierite-orthoamphibole rocks from the Rosebud syncline (Reinhardt, 1987) and evaporitic clays and shales (Jarousse, 1978). Also data from felsic volcanic rocks, basalts and clays and shales are given (Wedepohl, 1970, 1972, 1974, 1978; Handbook of Geochemistry and references therein). The figure is modified after Reinhardt (1987).

clays. The scandium abundances are too low in mafic volcanic rocks to be likely protoliths. On the other hand, the $\mathrm{Cr}$ concentrations are too high and the $\mathrm{Nb}$ concentrations too low for felsic volcanic rocks. In summary, trace element data from the cordierite-orthoamphibole rocks in the Rajapalot area are more consistent with a sedimentary, rather than volcanic, origin.

A sedimentary origin for the cordieriteorthoamphibole rocks would require protoliths that are rich in $\mathrm{Mg}, \mathrm{Fe}$, and $\mathrm{Al}$ and low in $\mathrm{K}, \mathrm{Na}$ and Ca. Reinhardt (1987) suggested that rocks with a suitable composition are produced by accumulation of magnesian clays. In a saline continental setting, areas with low sedimentation rates typically favor formation of authigenic clays, such as Mg-rich palygorskite and sepiolite, which usually precipitate in lake-margin environments (Warren, 2016). In evaporitic settings, they are interbedded with clastic sediments and carbonates (Warren, 2016). Moine et al. (1981) used a $\mathrm{Ca}-\mathrm{Mg}$-Al ternary diagram to illustrate compositional variations between evaporitic and nonevaporitic sediments. They demonstrated that samples from evaporitic sequences are distinguished by their higher $\mathrm{Mg}$ contents compared to nonevaporitic platform sediments. In Fig. 16, the ternary diagram of Moine et al. (1981) is applied to the rocks in the Palokas area. Cordieriteorthoamphibole rocks plot in the middle part of the $\mathrm{Al}-\mathrm{Mg}$ corner, where the palygorskite composition also occurs. Calcsilicate rocks plot in the central part of the diagram, in the field that represents the nonevaporitic platform sediments from Moine et al. (1981) and references therein.

The claystone-siltstone-sandstone-dolostone association of the Petäjäskoski Formation contains abundant disseminated hematite in many places, implying an oxidizing environment. Kyläkoski et al. (2012) proposed that the Petäjäskoski Formation at least partly represents a basin-wide meta-evaporitic sequence, possibly in a tidal environment. In the Rajapalot area, the rocks adjacent to the mineralized rocks are typically reddish to greenish, oxidized calcsilicate-albite rocks containing variable amounts of carbonates. The red color in the calcsilicate-albite rocks is most probably caused by hematite pigment, as no crystalline hematite 
Figure 15. Trace element composition of cordieriteorthoamphibole rocks from Palokas compared with reference data from the literature. Runkaus and Jouttiaapa Formation data after Geological Survey of Finland (unpublished). Bitumen rock data are unpublished data from Mawson Resources Ltd.

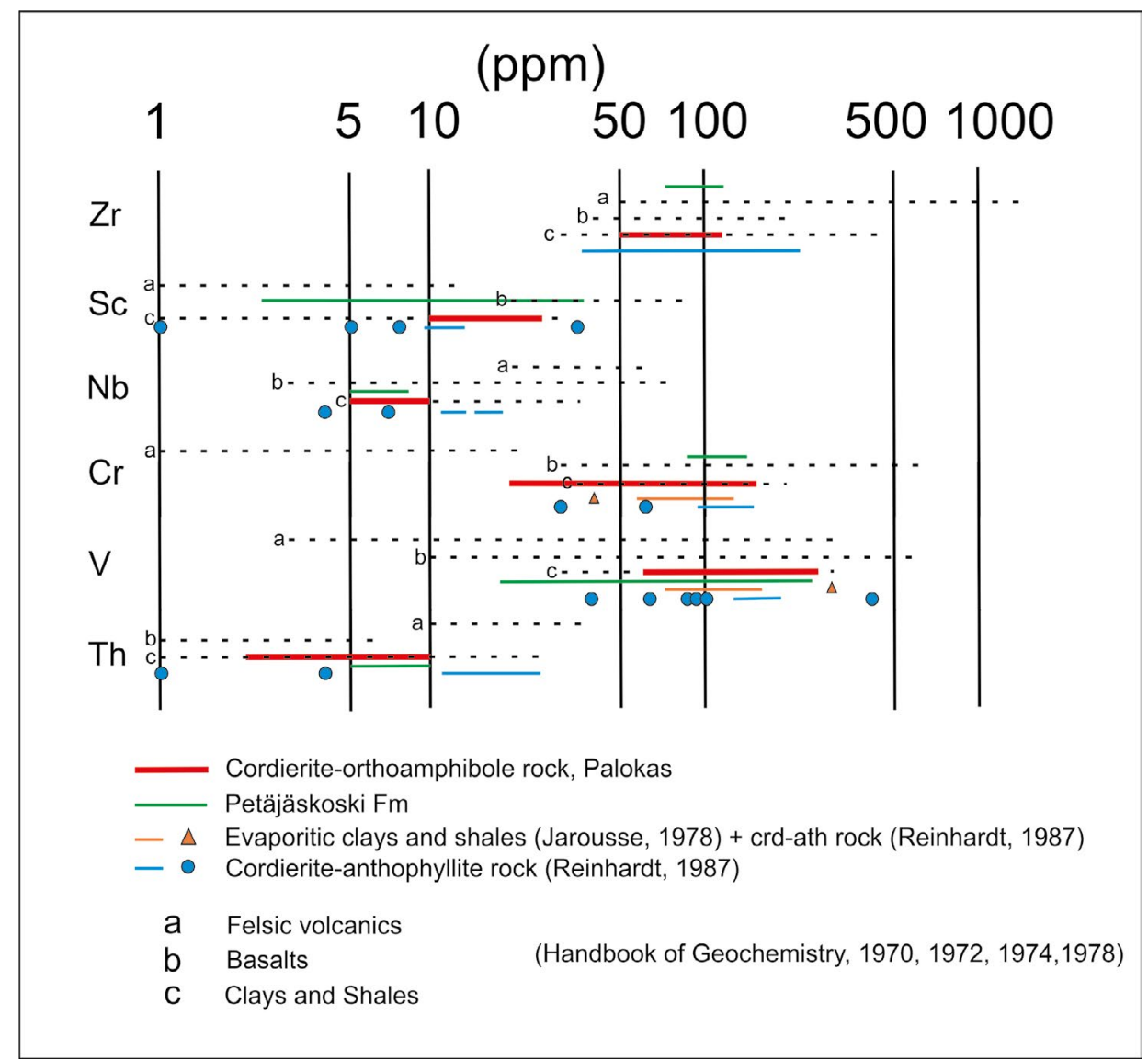

has been observed. Farther south of the Palokas occurrence, rocks with abundant phlogopite have been discovered by drilling (Mawson Resources Ltd. internal report). This rock association with oxidized albitic rocks and $\mathrm{Mg}$-rich schists closely resembles rocks in the Petäjäskoski Formation (Kyläkoski et al., 2012). Furthermore, these two areas are not located very far from each other; the closest known occurrence of the Petäjäskoski Formation intersected by drilling is only a few kilometers south of the Rajapalot area.

To further assess the evaporitic nature of the Petäjäskoski Formation, Ranta et al. (2017) analyzed boron isotope composition of tourmaline found in the quartz-phlogopite schists of the Petäjäskoski Formation. Tourmaline in the Petäjäskoski Formation, as described by Ranta et al. (2017), is not texturally as late as that at Palokas and, thus, is potentially not related to a late- to post-orogenic magmatic-hydrothermal event, but rather to the metamorphism of rocks with an appropriate primary mineralogy and chemical composition. The analyzed tourmaline grains from the Palokas occurrence, Petäjäskoski Formation, and $1.78 \mathrm{Ga}$ granite near Palokas show a short range of $\delta^{11} \mathrm{~B}$ values from zero to slightly negative (Ranta et al., 2017), implying that they share a common boron source. Tourmaline related to marine evaporites usually has a heavy $\delta^{11} \mathrm{~B}$ signature, extending up to about $+20 \%$ (Palmer \& Swihart, 1996), and, hence, boron in the analyzed rocks was not derived from marine evaporites. However, the $\delta^{11} \mathrm{~B}$ range of tourmaline from non-marine evaporites overlap with the compositions obtained by Ranta et al. (2017). To explain the homogeneous $\delta^{11} \mathrm{~B}$ signature, despite the apparently different times of formation 


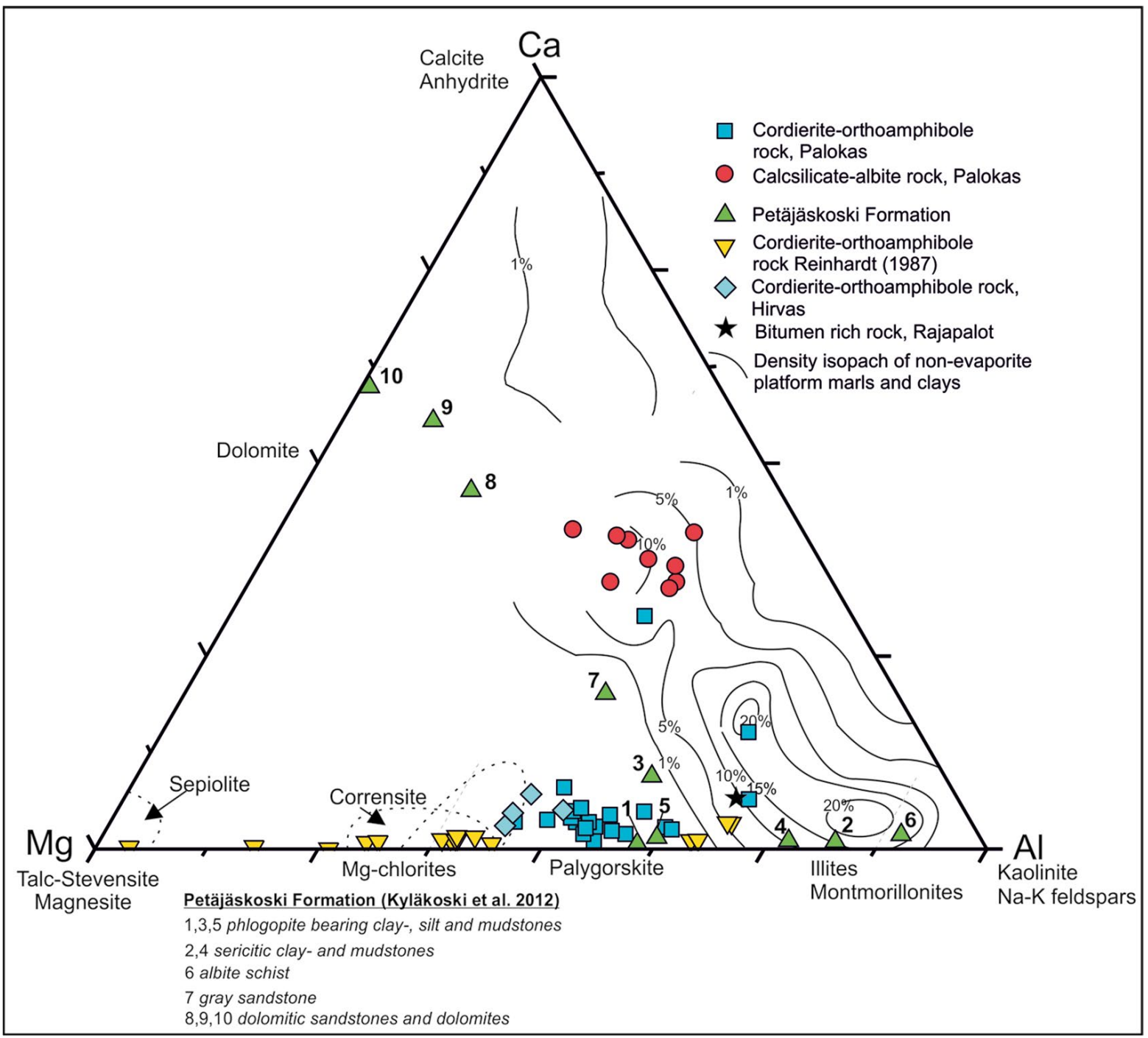

Figure 16. Al-Mg-Ca ternary diagram modified after Moine et al. (1981) and Warren (2016). Density isopachs show the distribution of shales and marls from common platform series (data after Moine et al. (1981). Bitumen rock data are unpublished data from Mawson Resources Ltd. Runkaus and Jouttiaapa data after Geological Survey of Finland (unpublished).

of the metamorphic tourmaline in the quartzphlogopite schists (Petääskoski Formation), the late-to post-metamorphic tourmaline at Palokas and the late- to post-orogenic tourmaline in the granite, we must consider the characteristics of the tourmaline-rich granite. It has been argued that the source of boron-rich magmas, which crystallize tourmaline, must be itself rich in boron and that the rocks containing tourmaline could be suitable source (London, 1999). Argillaceous and evaporitic sediments are one important source of boron in arid, closed-basin environments. The peraluminous bulk composition of the tourmaline granite and its $\mathrm{Nd}$ isotope and trace element composition indicate an origin by crustal melting (Ranta et al., 2015b). Based on the homogeneous boron isotope values 
reported by Ranta et al. (2017), it is possible that the source for the boron-rich melts of the $1.78 \mathrm{Ga}$ pegmatites was the tourmaline-bearing Petäjäskoski Formation, or at least the granitic melts assimilated parts of the Petäjäskoski Formation, inheriting the $\delta^{11} \mathrm{~B}$ signature from this source. A similar uniformity in boron isotope compositions between basement lithologies and later granites has also been reported in other studies (e.g., Trumbull et al., 2008).

Albitization is a typical phenomenon during sedimentation and diagenetic processes in evaporitic sequences, where dissolution of halite produces fluids rich in sodium (e.g., Warren, 2016). Widespread $\mathrm{Na}$ metasomatism has occurred in the Peräpohja belt and in other similar Paleoproterozoic supracrustals sequences shield-wide (e.g., Cook \& Ashley, 1992; Vanhanen, 2001; Melezhik et al., $2012,2015)$. The source of salts in the hydrothermal fluids that produced such a regionally extensive $\mathrm{Na}$ (and also $\mathrm{Cl}$ ) alteration has been proposed to be the abundant early Paleoproterozoic salt deposits, which were remobilized and largely dissolved during orogenic, magmatic, and metamorphic processes (e.g., Melezhik et al., 2015). A well-preserved record of this time interval is represented by the $>200$-meter-thick halite and massive anhydrite strata discovered by drilling from the Onega Basin, Russian Karelia (e.g., Melezhik et al., 2012). Based on widespread regional albitization and inferred evaporitic rock units, the former presence of similar salt deposits have been proposed from the Kuusamo belt (Vanhanen, 2001; Vasilopoulos et al., 2016), the Peräpohja belt (Kyläkoski et al., 2012), and the Alta-Kvanangen tectonic window in northern Norway (Melezhik et al., 2015).

In evaporitic basins, impure carbonatebearing clastic sediments, i.e. marls, are common (Moine et al., 1981; Warren, 2016). Based on the current metamorphic mineral assemblages of the calcsilicate-albite rocks in the Rajapalot area, we propose that they were originally calciticdolomitic marls, which were metamorphosed under amphibolite facies, producing calcsilicate minerals.
Later, the prograde diopside was partly replaced by tremolite when the temperature decreased.

In addition to the above-mentioned rock types, a relatively thick $(-60 \mathrm{~m})$, black, bituminous rock unit has been intersected by drilling in the northern part of the Rajapalot area. Veins of black bituminous material $(-0.5 \mathrm{~m}$ thick $)$ have also been found to cut mafic rocks in outcrops. The carbonaceous material closely resembles shungite, black and dense amorphous carbon-silicate rock documented within the Zaonega Formation in the Lake Onega region, Russian Karelia (Melezhik et al., 1999; Melezhik et al., 2012). Melezhik et al. (1999) concluded that these rocks represent the earliest stages of petroleum generation in the global geological record with both autochthonous bitumen (now pyrobitumen) and migrated bitumen (originally petroleum). In lacustrine evaporitic settings, accumulation of oil shales is common during lake high-stand periods (Warren, 2016). The black pyrobituminous unit in the Rajapalot area could represent such a highstand period of a lacustrine basin where oil shale deposition and migration of hydrocarbons took place. This further supports the evaporitic model for the Rajapalot rocks.

In summary, we propose that the metasedimentary units in the Rajapalot area are part of a basinwide lacustrine and, at least partly, evaporitic sequence. The lacustrine basin fill (see lake types in Bohacs et al., 2000) typically evolves during the depositional history from fluvial-lacustrine to more evaporitive lake types (Lambiase, 1990; Warren, 2016). The cordierite-orthoamphibole rocks represent originally lake margin sediments with abundant accumulation of Mg-rich clays. In addition, the bituminous rocks in the area could represent oil shale, typically formed in isolated basins during their high-stand periods. The pyrobitumen in the Rompas Au deposit (Molnár et al., 2016) provide evidence for migration of these hydrocarbons. 


\section{Conclusions}

Based on the petrographic, geochemical, and fluid inclusion characteristics of the Palokas area, the following conclusions can be drawn:

1. Native gold occurs in different textural types: a) single, relatively coarse grains within rock-forming silicates in cordieriteorthoamphibole rocks, and b) grains in fractures of tourmaline in quartz-sulfidetourmaline veins and in fractures of chloritized cordierite-orthoamphibole rocks adjacent to the tourmaline-rich veins. Fracture-related gold is associated with $\mathrm{Bi}$ Se-S-bearing tellurides, native bismuth, molybdenite, chalcopyrite, and pyrrhotite.

2. Fluid inclusions indicate that tourmaline in the gold-bearing veins was precipitated in boiling system under pressure conditions ranging from lithostatic to hydrostatic at a temperature of around $300^{\circ} \mathrm{C}$ and a depth of $\sim 5 \mathrm{~km}$.

3. Based on the whole-rock geochemistry, it is suggested that the cordierite-orthoamphibole rocks and interlayered calcsilicate-albite rocks originally formed part of a basin-wide lacustrine and at least partly evaporitic sequence. The cordierite-orthoamphibole rocks represent lake margin sediments with an abundant accumulation of $\mathrm{Mg}$-rich clays.

4. There seems to be a temporal, spatial, and genetic link between the ca. 1.78 Ga magmatism and fracture-related gold, as proposed earlier by Molnár et al. (2016) and
Ranta et al. (2017). However, the available exposures, drill core and observations on the geology and structures of the study area are not yet sufficient for the assignment of the Palokas Au occurrence or the whole RompasRajapalot system to any specific genetic class of gold deposits. Consequently, further studies on the geological, geochemical and mineralogical characteristics of the area are needed in order to better understand the genetic type of its gold mineralization.

\section{Acknowledgements}

This work was supported by the K.H. Renlund Foundation, Mawson Resources Limited, Advanced Material Doctoral Program (University of Oulu), and project No. 281670 "Mineral Systems and Mineral Prospectivity in LaplandMinSysPro" co-funded by the Academy of Finland and Geological Survey of Finland. Yann Lahaye is thanked for conducting tourmaline trace-element analyses. Leena Palmu is thanked for help during electron microprobe analyses. Csaba Szabo, Lazslo Aradi and Marta Berkesi are warmly thanked for help and support during the acquisition and interpretation of the Raman spectroscopic data. We are grateful to Marco Fiorentini and an anonymous reviewer for their useful comments and suggestions that significantly improved the manuscript.

\section{Supplementary data}

Electronic Appendices $\mathrm{A}-\mathrm{C}$ for this article are available via Bulletin of the Geological Society of Finland web page. 


\section{References}

Ahtonen, N., Hölttä, P. \& Huhma, H., 2007. Intracratonic Palaeoproterozoic granitoids in northern Finland: prolonged and episodic crustal melting events revealed by $\mathrm{Nd}$ isotopes and $\mathrm{U}-\mathrm{Pb}$ ages on zircon. Bulletin of the Geological Society of Finland 79, 143-174. https://doi.org/10.17741/bgsf/79.2.002

ALS Global (2017) Geochemistry, Schedule of Services and Fees. 42 p. Available online: https://www.alsglobal.com/myals/downloads

Baker, T. \& Lang, J.R., 2001. Fluid inclusion characteristics of intrusion-related gold mineralization, Tombstone tungsten magmatic belt, Yukon Territory, Canada. Mineralium Deposita 36, 563-582. https://doi.org/10.1007/s001260100189

Baker, T., 2002. Emplacement depth and $\mathrm{CO}_{2}$-rich fluid inclusions in intrusion-related gold deposits. Economic Geology 97, 1109-1115. https://doi.org/10.2113/gsecongeo.97.5.1111

Bohacs, K.M., Carroll, A.R., Neal, J.E. \& Mankiewicz, P.J., 2000. Lake-basin type, source potential, and hydrocarbon character: an intergrated sequencestratigraphic geochemical framework. In: GierlowskiKordesch, E.H. \& Kelts K.R. (eds.), Lake Basins Through Space and Time. AAPG Studies in Geology 46, 3-34.

Boynton, W.V., 1984. Cosmochemistry of the rare earth elements; meteorite studies. In: Henderson, P. (eds.), Rare Earth Element Geochemistry. Elsevier, Amsterdam, pp. 63-114.

Cook N., 2017. A new gold province for Finland Rompas and Rajapalot Projects, Mawson Resources. Presentation at FEM2017 conference. Available online: http://fem.lappi.fi/c/document_library/get_ file?folderId=3913831\&name=DLFE-32471.pdf

Cook, N.D.J. \& Ashley, P.M., 1992. Meta-evaporite sequence, exhalative chemical sediments and associated rocks in the Proterozoic Willyama Supergroup, South Australia: Implications for metallogenesis. Precambrian Research 56, 211-226. https://doi.org/10.1016/0301-9268(92)90102-T

Deer, H., 1992. An Introduction to the Rock-Forming Minerals. $2^{\text {nd }}$ Edition, Prentice Hall, 687 p.

Diamond, L., 2001. Review of the systematics of CO2-H2O fluid inclusions. Lithos 55, 69-99. https://doi.org/10.1016/S0024-4937(00)00039-6

Drummond, S.E. \& Ohmoto, H., 1985. Chemical evolution and mineral deposition in boiling hydrothermal systems. Economic Geology 80, 126-147. https://doi.org/10.2113/gsecongeo.80.1.126

Dyar, M.D., Wiedenbeck, M., Robertson, D., Cross, L.R., Delaney, J.S., Ferguson, K., Francis, C.A., Grew, E.S., Guidotti, C.V., Hervig, R.L., Hughes, J.M., Husler, J., Leeman, W., McGuire, A.V., Rhede, D., Rothe, H., Paul, R.L., Richards, I. \& Yates, M., 2001. Reference minerals for the Microanalysis of light elements. Geostandards Newsletter 25, 441-463.

https://doi.org/10.1111/j.1751-908X.2001.tb00616.x

Eilu, P., 1994. Hydrothermal alteration in volcano sedimentary rocks in the Central Lapland greenstone belt, Finland. Geological Survey of Finland, Bulletin 374, 145 p.

Eilu, P., 2015. Overview on gold deposits in Finland. In: Maier, W.D., O’Brien, H., Lahtinen, R. (eds.), Mineral Deposits of Finland, Elsevier, Amsterdam, pp. 377-403. https://doi.org/ 10.1016/B978-0-12-410438-9.00015-7

Elliott-Meadows, S.R., Froese, E. \& Appleyard, E.C., 2000. Cordierite-anthophyllite-cummingtonite rocks from the Lar deposit, Laurie Lake, Manitoba. Canadian Mineralogist 38, 545-550.

https://doi.org/10.2113/gscanmin.38.2.545

Eskola, P., 1914. On the petrology of the Orijärvi region in southwestern Finland. Bulletin de la Comission géologique de Finlande 40, 1-279.

Gál, B., Molnár, F., Guzmics, T., Mogessie, A., Szabó, C. \& Peterson, D.M., 2013. Segregation of magmatic fluids and their potential in the mobilization of platinum-group elements in the South Kawishiwi Intrusion, Duluth Complex, Minnesota — Evidence from petrography, apatite geochemistry and coexisting fluid and melt inclusions. Ore Geology Reviews 54, 59-80. https://doi.org/10.1016/j.oregeorev.2013.03.001

Goldfarb, R.J. \& Groves, D.I., 2015. Orogenic gold: Common or evolving fluid and metal sources through time. Lithos 233, 2-26. https://doi.org/10.1016/j.lithos.2015.07.011

Goldfarb, R.J., Groves, D.I. \& Gardoll, S., 2001. Orogenic gold and geological time: a global synthesis. Ore Geology Reviews 18, 1-75. https://doi.org/10.1016/S0169-1368(01)00016-6

Goldfarb, R.J., Baker, T., Dube, B., Groves, D.I., Hart, G.J.R. \& Gosselin, P., 2005. Distribution, character, and genesis of gold deposits in metamorphic terranes. Economic Geology 100, 407-450. https://doi.org/10.5382/AV100.14

Groves, D.I., 1993. The crustal continuum model for lateArchaean lode-gold deposits of the Yilgarn Block, Western Australia. Mineralium Deposita 28, 366-374. https://doi.org/10.1007/bf02431596

Groves, D.I., Goldfarb, R.J., Gebre-Mariam, M., Hagemann, S.G. \& Robert F., 1998. Orogenic gold deposits: A proposed classification in the context of their crustal distribution and relationships to other deposit types. Ore Geology Reviews 13, 7-27. https://doi.org/10.1016/S0169-1368(97)00012-7

Haas, J.R., Shock, E.L. \& Sassani, D.C., 1995. Rare earth elements in hydrothermal systems: estimates of standard partial molal thermodynamic properties of aqueous complexes of the rare earth elements at high pressures 
and temperatures. Geochimica Cosmochimica Acta 59, 4329-4350. https://doi.org/10.1016/0016-7037(95)00314-P

Hanski, E., Huhma, H. \& Perttunen, V., 2005. SIMS U-Pb, $\mathrm{Sm}-\mathrm{Nd}$ isotopic and geochemical study of an arkositeamphibolite suite, Peräpohja Schist Belt: Evidence for $1.98 \mathrm{Ga}$ A-type felsic magmatism in northern Finland. Bulletin of Geological Society of Finland 77, 5-29. https://doi.org/ 10.17741/bgsf/77.1.001

Hanski, E., Huhma, H. \& Vuollo, J., 2010. SIMS zircon ages and $\mathrm{Nd}$ isotope systematics of the $2.2 \mathrm{Ga}$ mafic intrusions in northern and eastern Finland. Bulletin of the Geological Survey of Finland 82, 31-62. https://doi.org/10.17741/bgsf/82.1.002

Hart, C.J.R. \& Goldfarb, R.J., 2005. Distinguishing intrusionrelated from orogenic gold systems. Proceedings of $\mathrm{New}$ Zealand Minerals Conference: realising New Zealand's mineral potential, 13-16 November 2015, Auckland, New Zealand. pp. 125-133.

Hawthorne, F.C., Oberti, R., Harlow, G.E., Maresch, W.V., Martin, R.F., Schumacher, J.C. \& Welch, M.D., 2012. Nomenclature of the amphibole supergroup. American Mineralogist 97, 2031-2048. https://doi.org/10.2138/am.2012.4276

Hazarika, P., Mishra, B. \& Pruseth, K.L., 2015. Diverse tourmaline compositions from orogenic gold deposits in the Hutti-Maski Greenstone Belt, India: implications for sources of ore-forming fluids. Economic Geology 110 , 337-353.

https://doi.org/ 10.2113/econgeo.110.2.337

Henry, D.J. \& Dutrow, B.L., 1996. Metamorphic tourmaline and its petrologic applications. In: Grew, E.S. \& Anovitz, L.M. (eds.), Boron: Mineralogy, Petrology and Geochemistry. Reviews in Mineralogy 33, 503-557.

Henry, D.J., Guidotti, C.V. \& Thomson, J.A., 2005. The Ti-saturation surface for low-to-medium pressure metapelitic biotite: Implications for geothermometry and Ti-substitution mechanisms. American Mineralogist 90, 316-328.

https://doi.org/10.2138/am.2005.1498

Hensen, B.J. \& Zhou, B., 1995. Retention of isotopic memory in garnets partially broken down during an overprinting granulite-facies metamorphism: implications for the SmNd closure temperature. Geology 23, 225-228.

https://doi.org/10.1130/00917613(1995)023<0225:ROIMIG>2.3.CO;2

Hey, M.H., 1954. A new review of the chlorites. Mineralogical Magazine 30, 277-292.

https://doi.org/10.1180/minmag.1954.030.224.01

Hölttä, P. \& Heilimo, E., 2017. Metamorphic map of Finland. Geological Survey of Finland, Special Paper 60, 75-126.

Hölttä, P., Väisänen, M., Väänänen, J. \& Manninen, T., 2007. Paleoproterozoic metamorphism and deformation in Central Finnish Lapland. Geological Survey of Finland, Special Paper 44, 109-120.
Hudson, M., 2013. Progress report on the geology, mineralization and exploration activities on the RompasRajapalot gold-uranium project, Peräpohja schist belt. Mawson Resources Ltd. 2003, 53 p. Available online: http://mawsonresources.com/assets/docs/ reports/2013-08_ni43-101-rompas.pdf

Huhma, H., Cliff, R.A., Perttunen, V. \& Sakko, M., 1990. Sm$\mathrm{Nd}$ and $\mathrm{Pb}$ isotopic study of mafic rocks associated with early Proterozoic continental rifting: the Peräpohja Schist Belt in northern Finland. Contribution to Mineralogy and Petrology 104, 369-379.

https://doi.org/ 10.1007/BF00321491

Iljina, M. \& Hanski, E., 2005. Layered mafic intrusions of the Tornio-Näränkävaara Belt. In: Lehtinen, M., Nurmi, P.A. \& Rämö, O.T., (eds.), Precambrian Geology of Finland - Key to the Evolution of the Fennoscandian Shield, Elsevier, Amsterdam, pp. 101-138.

Jarousse, J., 1978. Contribution au probleme de I'identification d'anciennes stries evaporitiques dans les ensembles metamorphiques. Approche principalement geochimique. These 3eme cycle, Universite Claude Bernard, Lyon. 232 p.

Jochum, K.P., Wels, U., Stoll, B., Kuzmin, D., Yang, Q., Raczek, I., Jacob, D.E., Stracke, A., Birbaum, K., Frick, D.D., Günther, D., Enzweiler, J., 2011. Determination of Reference values for NIST SRM 610617 glasses following ISO guidelines. Geostandards and Geoanalytical Research 35, 397-429. https://doi. org/10.1111/j.1751-908X.2011.00120.x https://doi.org/10.1111/j.1751-908X.2005.tb00901.x

Kalliomäki, H., Wagner, T., Fusswinkel, T. \& Sakellaris, G., 2017. Major and trace element geochemistry of tourmalines from Archean orogenic gold deposits: Proxies for the origin of gold mineralizing fluids? Ore Geology Reviews 91, 906-927. https://doi.org/10.1016/j.oregeorev.2017.08.014

Karhu, J., Kortelainen, N., Huhma, H., Perttunen, V. \& Sergeev, S., 2007. New time constraints for the end of the Paleoproterozoic carbon isotope excursion. In: $7^{\text {th }}$ Symposium on Applied Isotope Geochemistry, Steelenbosch, South Africa, $10^{\text {th }}-14^{\text {th }}$ September, 2007, Abstracts, pp. 76-77.

Kyläkoski, M., Hanski, E. \& Huhma, H., 2012. The Petäjäskoski Formation, a new lithostratigraphic unit in the Paleoproterozoic Peräpohja Belt, northern Finland. Bulletin of the Geological Society of Finland 84, 85-120. https://doi.org/10.17741/bgsf/84.2.001

Lahtinen, R., Mohammad, S. \& Fredrik, K., 2015. Nearorthogonal deformation successions in the polydeformed Proterozoic Martimo belt: Implications for the tectonic evolution of Northern Fennoscandia. Precambrian Research 270, 22-38. https://doi.org/10.1016/j.precamres.2015.09.003

Lambiase, J.J., 1990. A model for tectonic control of lacustrine stratigraphic sequences in continental rift basins. In: Katz 
BJ (eds) Lacustrine Basin Exploration-Case Studies and Modern Analogues. AAPG Memoir 50, 265-276.

Lang, J.R., Baker, T., Hart, C.J.R. \& Mortensen, J.K., 2000. An exploration model for intrusion-related gold systems. Society of Economic Geologists Newsletter 40, 1-15.

Lauerma, R., 1982. On the ages of some granitoid and schist complexes in northern Finland. Bulletin of Geological Society of Finland 54, 85-100. https://doi.org/10.17741/bgsf/54.1-2.009

Lauri, L.S., Andersen, T., Räsänen, J. \& Juopperi, H., 2012. Temporal and Hf isotope geochemical evolution of southern Finnish Lapland from 2.77 Ga to $1.76 \mathrm{Ga}$. Bulletin of the Geological Society of Finland 84, 121-140. https://doi.org/10.17741/bgsf/84.2.002

Locock, A.J., 2014. An excel spreadsheet to classify chemical analyses of amphiboles following the IMA 2012 recommendations. Computer \& Geosciences 62, 1-11. https://doi.org/10.1016/j.cageo.2013.09.011

London, D., 1999. Stability of tourmaline in peraluminous granite systems: the boron cycle from anatexis to hydrothermal aureoles. European Journal of Mineralogy 11,253-262. https://doi.org/10.1127/ejm/11/2/0253

Melezhik, V.A., Fallick, A.E., Filippov, M.M. \& Larsen, O., 1999. Karelian shungite - an indication of $2000 \mathrm{Ma}$ year old metamorphosed oil shale and generation of petroleum: geology, lithology and geochemistry. Earth Science Reviews 47, 1-40. https://doi.org/10.1016/S0012-8252(99)00027-6

Melezhik, V.A., Medvedev, P.V. \& Svetov, S.A. 2012. The Onega basin. In: Melezhik, V.A., Prave, A.R., Hanski, E.J., Fallick, A.E., Lepland, A., Kump, L.R. \& Strauss, H., (eds.) Reading the Archive of Earth's Oxygenation, Volume 1: The Palaeoproterozoic of Fennoscandia as Context for the Fennoscandian Arctic Russia. Drilling Early Earth Project. Springer-Verlag, Berlin Heidelberg. https://doi.org/10.1007/978-3-642-29682-6_9

Melezhik, V.A., Bingen, B., Sandstad, J.S., Pokrovsky, B.G., Solli, A. \& Fallick, A.E., 2015. Sedimentary-volcanic successions of the Alta-Kvaenangen Tectonic Window in the northern Norwegian Caledonides: Multiple constraints on deposition and correlation with complexes on the Fennoscandian shield. Norwegian Journal of Geology 95, 245-284. https://doi.org/10.17850/njg95-3-01

Mezger, K., Essene, E.J. \& Halliday, A.N., 1992. Closure temperature of the $\mathrm{Sm}-\mathrm{Nd}$ system in metamorphic garnets. Earth and Planetary Science Letters 113, 397409.

https://doi.org/10.1016/0012-821X(92)90141-H

Moine, B., Sauvan, P. \& Jarousse, J., 1981. Geochemistry of evaporite-bearing series: a tentative guide for the identification of metaevaporites. Contributions to Mineralogy and Petrology 76, 401-412.

https://doi.org/10.1007/bf00371482
Molnár, F., Oduro, H., Cook, N.D.J., Pohjolainen, E., Takacs, A., O’Brien, H., Pakkanen, L., Johanson, B. \& Wirth, R., 2016. Association of gold with uraninite and pyrobitumen in the metavolcanic rock hosted hydrothermal Au-U mineralization at Rompas, Peräpohja Schist Belt, northern Finland. Mineralium Deposita 51, 681-702. https://doi.org/ 10.1007/s00126-015-0636-6

Molnár, F., O`Brien, H., Stein, H. \& Cook, N., 2017 a. Geochronology of hydrothermal processes leading to the formation of the Au- $\mathrm{U}$ mineralization at the Rompas prospect, Peräpohja belt, Northern Finland: Application of paired U-Pb dating of uraninite and $\mathrm{Re}-\mathrm{Os}$ dating of molybdenite to the identification of multiple hydrothermal events in a metamorphic terrane. Minerals $7: 171$. https://doi.org/10.3390/min7090171

Molnár, F., O’Brien, H., Lahaye, Y., Kurhila, M., Middleton A. \& Johanson, B., 2017b. Multi-stage hydrothermal processes and diverse metal associations in orogenic gold deposits of the Central Lapland Greenstone Belt, Finland. Mineral Resources to Discover $-14^{\text {th }}$ SGA Biennial Meeting 2017, Volume 1, 63-66.

Nironen, M., 2005. Proterozoic orogenic granitoid rocks. In: Lehtinen, M., Nurmi, P.A. \& Rämö, O.T. (eds.), Precambrian Geology of Finland-Key to the Evolution of the Fennoscandian Shield. Elsevier, Amsterdam, pp. 443-479.

Nironen, M., 2017 Structural interpretation of the Peräpohja and Kuusamo belts and Central Lapland, and a tectonic model for northern Finland. Geological Survey of Finland, Report of Investigation 234, 53 p.

Nykänen, V., Niiranen, T., Molnár, F., Lahti, I., Korhonen, K., Cook, N. \& Skyttä, P., 2017. Optimizing a knowledgedriven prospectivity model for gold deposits within Peräpohja Belt, Northern Finland. Natural Resources Research 26, 571-584. https://doi.org/ 10.1007/s11053-016-9321-4

Palmer, M.R. \& Swihart, G.H., 1996. Boron isotope geochemistry: an overview. In: Grew, E.S. \& Anovitz, L.M (eds.), Boron: Mineralogy, Petrology, and Geochemistry. Reviews in Mineralogy 33, 709-744.

Pan, Y. \& Fleet, M.E., 1995. Geochemistry and origin of cordierite-orthoamphibole gneiss and associated rocks at an Archaean volcanogenic massive sulfide camp: Manitouwadge, Ontario, Canada. Precambrian Research 74, 73-89.

https://doi.org/ 10.1016/0301-9268(95)00010-3

Peck, W.H. \& Smith, M.S., 2005. Cordierite-gedrite rocks from the Central Metasedimentary Belt boundary thrust zone (Grenville Province, Ontario): Mesoproterozoic metavolcanic rocks with affinities to the Composite Arc Belt. Canadian Journal of Earth Sciences 42, 1815-1828. https://doi.org/10.1139/e05-071 
Perttunen, V., Hanski, E. \& Väänänen, J., 1995. Stratigraphical map of the Peräpohja Schist Belt. In: 22 $2^{\text {nd }}$ Nordic Geological Winter Meeting, January 8-11, 1996s, Turku, Abstracts, p. 152.

Perttunen, V. \& Vaasjoki, M., 2001. U-Pb geochronology of the Peräpohja Schist Belt, northwestern Finland. Geological Survey of Finland, Special Paper 33, 45-84.

Pitra, P., Boulvais, P., Antonoff, V. \& Diot, H., 2008. Wagnerite in cordierite-gedrite gneiss: Witness of long-term fluid-rock interaction in continental crust (lle d' Yeu, Armorican Massif, France). American Mineralogist 93, 315-326. https://doi.org/10.2138/am.2008.2597

Ranta, J.P., Hanski, E. \& Cook, N., 2015a. Petrography and mineral geochemistry of the Paleoproterozoic Palokas Au mineralization. Proceeding of the $13^{\text {th }}$ Biennial SGA Meeting, 24-27 August 2015, Nancy, France, pp. 193196

Ranta, J.P., Lauri, L.S., Hanski, E., Huhma, H., Lahaye, Y. \& Vanhanen, E., 2015b. U-Pb and Sm-Nd isotopic constraints on the evolution of the Paleoproterozoic Peräpohja Belt, northern Finland. Precambrian Research 266, 246-259.

https://doi.org/10.1016/j.precamres.2015.05.018

Ranta, J.P., Hanski, E., Cook, N. \& Lahaye, Y., 2017. Source of boron in the Palokas gold deposit, northern Finland: Evidence from boron isotopes and major element composition of tourmaline. Mineralium Deposita 52, 733-746.

https://doi.org/10.1007/s00126-016-0700-x

Reimann, C. \& Filzmoser, P., 2000. Normal and lognormal data distribution in geochemistry: death of a myth. Consequences for the statistical treatment of geochemical and environmental data. Environmental Geology 39, 1001-1014. https://doi.org/10.1007/s002549900081

Reimann, C., Filzmoser, P., Garrett, R.G. \& Dutter, R., 2008. Statistical Data Analysis Explained: Applied Environmental Statistics with R. Wiley, Chichester, 362 p.

Reinhardt, J., 1987. Cordierite-anthophyllite rocks from north-west Queensland, Australia: metamorphosed magnesian pelites. Journal of Metamorphic Geology 5, 451-472. https://doi.org/10.1111/j.1525-1314.1987.tb00396.x

Roedder, E., 1984. Fluid Inclusions. Reviews in Mineralogy 12, $646 \mathrm{p}$.

Roberts, M.D., Oliver, N.H.S., Fairclough, M.C., Hölttä, P.S. \& Lahtinen, R., 2003. Geochemical and oxygen isotope signature of sea-floor alteration associated with a polydeformed and highly metamorphosed massive sulfide deposit, Ruostesuo, central Finland. Economic Geology 98, 535-556. https://doi.org/10.2113/98.3.535

Schumacher, J.C., 1988. Stratigraphy and geochemistry of the Ammonoosuc volcanics, central Massachusetts and southwestern New Hampshire. American Journal of Science 288, 619-663.

https://doi.org/ 10.2475/ajs.288.6.619

Sillitoe, R.H., 1991. Intrusion-related gold deposits. In: Foster, R.P. (ed.), Gold Metallogeny and Exploration. Blackie and Sons Ltd, Glasgow, pp. 165-209.

Sverjensky, D.A., 1984. Europium redox equilibria in aqueous solution. Earth and Planetary Science Letters 67, 70-78. https://doi.org/ 10.1016/0012-821X(84)90039-6

Taylor, S.R. \& McLennan, S.C., 1995. The geochemical evolution of the continental crust. Reviews of Geophysics 33, 241-265.

https://doi.org/10.1029/95RG00262

Thiéry, R., Van Den Kerkhof, A.M. \& Dubessy, J., 1994. vX properties of $\mathrm{CH}_{4}-\mathrm{CO}_{2}$ and $\mathrm{CO}_{2}-\mathrm{N}_{2}$ fluid inclusions: modelling for $\mathrm{T}<31{ }^{\circ} \mathrm{C}$ and $\mathrm{P}<400$ bars. European Journal of Mineralogy 6, 753-771. https://doi.org/10.1127/ejm/6/6/0753

Thompson, J.F.H. \& Newberry, R.J., 2000. Gold deposits related to reduced granitic intrusions. Reviews in Economic Geology 13,377-400. https://doi.org/10.5382/Rev.13.11

Trumbull, R.B., Krienitz, M.S., Gottesmann, B. \& Wiedenbeck, M., 2008. Chemical and boron-isotope variations in tourmalines from an S-type granite and its source rocks: the Erongo granite and tourmalinites in the Damara Belt, Namibia. Contributions to Mineralogy and Petrology 155, 1-18. https://doi.org/ 10.1007/s00410-007-0227-3

Väänänen, J., 2004. Sieppijärvi and Pasmajärvi. Explanation to the Geological map of Finland 1:100 000, preQuaternary rocks, sheets 2624 and 2642, Geological Survey of Finland, 55 p. (in Finnish with English summary).

Vanhanen, E., 2001. Geology, mineralogy and geochemistry of the Fe-Co-Au-(U) deposits in the Paleoproterozoic Kuusamo schist Belt, northeastern Finland. Geological Survey of Finland, Bulletin 399, 229 p.

Vanhanen, E., Cook, N.D.J., Hudson, M.R., Dahlenborg, L., Ranta, J.P., Havela, T., Kinnunen, J., Molnár, F., Prave, A.R. \& Oliver, N.H.S., 2015. Rompas prospect, Peräpohja Schist Belt, northern Finland. In: Maier, W.D., O’Brien, H. \& Lahtinen, R (eds.), Mineral Deposits of Finland. Elsevier, Amsterdam, pp. 467-484. https://doi.org/10.5382/econgeo.112.6.br03

Vasilopoulos, M., Lefebvre, M.G., Molnár, F., Richard, A. \& André-Mayer, A-S., 2016. Hydrothermal alteration and sources of fluids in the Juomasuo Au-Co deposit, Kuusamo Schist Belt, Finland. Abstracts of the $32^{\text {nd }}$ Nordic Geological Winter Meeting, Helsinki, Finland. Bulletin of the Geological Society of Finland, Special Volume 1, p. 119.

Warren, J.K., 2016. Evaporite, a Geological Compendium, $2^{\text {nd }}$ Edition, Springer, Switzerland, $1822 \mathrm{p}$. https://doi.org/10.1007/978-3-319-13512-0 
Wedepohl, K.H. (ed.), 1970. Handbook of Geochemistry, vol. 2/2, Elements Si (41) to V(23). Springer-Verlag, Berlin. $667 \mathrm{p}$.

Wedepohl, K.H. (ed.), 1972, vol. 2/3, Elements Cr (24) to $\operatorname{Br}(35)$. Handbook of Geochemistry. Springer-Verlag, Berlin. $400 \mathrm{p}$.

Wedepohl, K.H. (ed.), 1974, vol. 2/4, Elements $\operatorname{Kr}(36)$ to $\mathrm{Ba}(56)$. Handbook of Geochemistry. Springer-Verlag, Berlin. $950 \mathrm{p}$.

Wedepohl, K.H. (ed.), 1978, vol. 2/5, Elements La(57) to $\mathrm{U}(92)$. Handbook of Geochemistry. Springer-Verlag, Berlin. $800 \mathrm{p}$.
Yavuz, F., Jiang, S.Y., Karakaya, N., Karakaya, M.C. \& Yavuz, R., 2011. Trace-element, rare-earth element and boron isotopic compositions of tourmaline from a vein-type $\mathrm{Pb}$ $\mathrm{Zn}-\mathrm{Cu} \pm \mathrm{U}$ deposit, NE Turkey. International Geological Review 53, 1-24. http://doi.org/10.1080/00206810902867401

Yardley, B.W.D. \& Cleverley, J.S., 2013. The role of metamorphic fluids in the formation of ore deposits. Geological Society, London. Special Publications 393, $117 \mathrm{p}$.

https://doi.org/10.1144/SP393.5. 